\title{
A Framework for Fuel-Cycle Approaches to IAEA Safeguards
}

\author{
By \\ BNL --38770 \\ Leslie G. Fishbone \\ DE87 002146 \\ With the Assistance of \\ William A. Higinbotham
}

October 1986

\author{
BROOKHAVEN NATIONAL LABORATORY \\ ASSOCIATED UNIVERSITIES, INC. \\ UPTON, LONG ISLAND, NEW YORK 11973 \\ UNDER CONTRACT NO. DE-AC02-76CH00016 WITH THE \\ UNITED STATES DEPARTMENT OF ENERGY
}

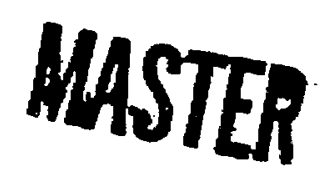


This report was prepared as an account of work sporisored by an Agency of the United States Government. Neither the United States nor the United States Department of Energy, nor any of their employees, nor any of their contractors, subcontractors, or their employees, makes any warranty, express or implied, or assumes any legal liability or responsibility for any accuracy, completeness, or useful ness of any information, apparatus, product, or process disclosed, or represents that its use would not infringe privately-owned rights. Further, neither the subject matter nor the content of this report reflects any policy, express or implied, by the United States Government. 


\section{ABSTRACT}

In order to compare several nuclear-safeguards verification approaches to one another and to the conventional facility-oriented approach, we establish a framework of the classes of information routinely verifiable by IAEA safeguards inspections. For each facility type within a state nuclear fuel cycle, the classes include flow data, inventory data, and shipper and receiver data. By showing which classes of information are verified for each facility type within three fuel cycles of different complexity, we distinguish the inspection approaches from one another and exhibit their fuel-cycle dependence, i.e., their need for sets of safeguards inspection activities different from those required under the facility-oriented approach at similar facilities in fuel cycles of differing complexity. Tables $V-1, V-2$, and $V-3$ graphically depict these relations and give a qualitative summary of the relative effectiveness and effort requirements of the approaches classified.

The zone, information-correlation, diversion-assumption-change, and randomization-over-facilities approaches depend intrinsically on the complexity of the fuel cycle: their very definition implies fuel-cycle dependence. The approaches involving randomization over activities and goal relaxations do not have such dependence. 


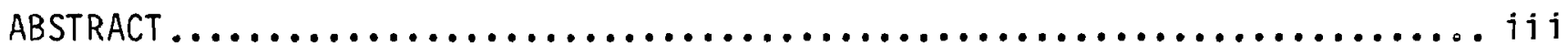

LIST OF TABLES............................................. vi

LIST OF FIGURES........................................... vi i

ACKNOWLEDGEMENT S..........................................

I. INTRODUCT ION.............................................. 1

I.1 Background of the Study............................. 1

I.2 Meaning of Fuel-Cycle Approaches......................... 2

I.3 Structure of This Report.......................... 3

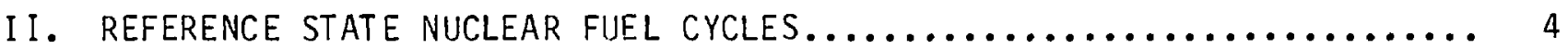

II.1 General Remarks..................................... 4

II.2 Reactors Only....................................... 4

II.3 Fresh-Fuel Facilities and Reactors....................... 4

I I.4 A Closed Fuel Cycle................................ 4

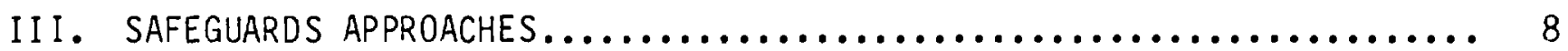

III.1 General As sumptions.................................. 9

III.2 The Facility-Oriented Approach......................... 9

III.2.1 The Fundamental Role of Materials Accountancy....... 9

III.2.2 Physical-Inventory Verifications (PIVs)........... 9

III.2.3 Fl ow-Measurement Verification.................. 10

II .2.4 Fuel-Cycle Aspects of the Facility-Oriented

Approach.................................... 10

III.2.5 Facility-Oriented Practical Considerations.......... 11

III.3 Fuel-Cycle Approaches.............................. 11

III.3.1 Information-Correlation Approach................. 11

III.3.2 Diversion-Path (DP) Analysis for the Fuel Cycle

as a Whole.................................... 12

III.3.3 The Zone Approach............................, 13

II I.3.3.1 General Description................... 13

III.3.3.2 Zone Materials Accountancy............. 13

III.3.3.3 Zone Physical-Inventory Verifications..... 14

III.3.3.4 The Choice of Zones................... 15

II 3.3.5 Zone-Approach Practical Considerations.... 16

III.3.4 Randomization............................. 16

II I.3.4.1 General Remarks....................... 16

I I 3.4 .2 Over Activities....................... 17

II 3.4 .3 Over Inspection Timing................ 17

III.3.4.4 Over Facilities....................... 17

II I.3.4.5 Over States......................... 17

I I .3.4.6 Randomization-Approach Summary......... 18

III.3.5 Inspection-Goal Relaxation....................... 18

III.3.6 Diversion-As sumption Changes................... 18 
IV. INFORMATION AS THE FRAMEWORK FOR COMPARING SAFEGUIARDS APPROACHES .... 20

IV.1 What Does the IAEA Routinely Verify?..................... 20

IV.2 Verifiable Information Classes Available from Generic

Inspection Types................................... 21

I .2 .1 Shipper and Receiver Data..................... 21

I V.2.2 Flow Data................................... 21

IV.2.3 Inventory Data........................... 22

V. FIJEL-CYCLE DESCRIPTION OF THE SAFEGUARDS APPROACHES ACCORDING TO

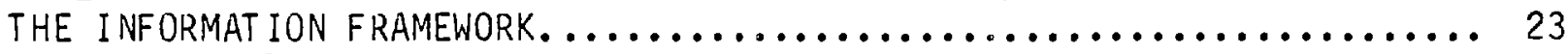

V.1 General Remarks.................................. 23

V.2 Comparison of the Approaches for Reactors Only............. 23

V.3 Comparison of the Approaches for Fresh-Fuel

Facilities and Reactors................................ 27

V.4 Comparison of the Approaches for a Closed Fuel Cycle ......... 30

VI. DISCUSSION......................................... 37

VI.1 Intrinsic and Extrinsic Fuel-Cycle Dependence............... 37

VI.2 Effort and Effectiveness Considerations.................... 37

VI.2.1 Effort..................................... 37

VI.2.2 Paragraph 81 Factors............................ 38

VI.2.3 Ef fectiveness................................ 39

VI.3 Limitations of the Framework Analysis...................... 40

VI.4 Further Work....................................... 40

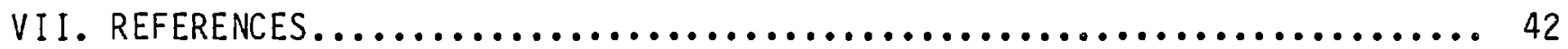

APPENDIX A : GLOSSARY.................................... 46

APPENDIX B: DUPLICATE SET OF TABLES $V-1, V-2, V-3 \ldots \ldots \ldots \ldots \ldots \ldots \ldots, 48$ 


\section{LIST OF TABLES}

$\underline{\text { Table }}$

Title Page

I I-1

$V-1$

$v-2$

$v-3$

VI-1

\section{LIST OF FIGURES}

Figure

I I-1

Fuel-Cycle Facilities. Reactors on ly

Title
Comparison of the Approaches for a Fuel Cycle With

Comparison of the Approaches for a Fuel Cycle with Fresh-Fuel Facilities and Reactors. 28 Comparison of the Approaches for a Closed Fuel Cycle.... 31 Classification of the Sa feguards Approaches...

Page

Zone structure and major annual nuclear material flows for the closed reference fuel cycle. 


\section{ACKNOWLEDGMENTS}

Our colleagues in the Technical Support Organization at Brookhaven, especially Gene Weinstock and Sylvester Suda; Frank Houck and Ken Sanders of the Arms Control and Disarmament Agency; Michael Rosenthal of the International Atomic Energy Agency; James de Montmollin of Sandia National Laboratories; Larry Wirfs, Carol Eberhard, and $\mathrm{Cl}$ arence Breskovic of the Nuclear Regulatory Commission; and Leon Green and Ann Reisman of the International Safeguards Project Office at Brookhaven commented helpfully on material in this report. We thank them for their suggestions and criticisms.

We are grateful to Judy Bada 1, Nora Davies, Denise Miesel1, Lynn Kelly and Lois Marascia for their preparation of the manuscript.

This report summarizes the work for Task SP.23 of the United States Program for Technical Assistance to IAEA Safeguards (POTAS), administered by the International Safeguards Project of fice at Brookhaven National Laboratory. 


\section{I.1 Background of the Study}

An International Atomic Energy Agency (IAEA) Consultants' Meeting on the Application of Safeguards to Multiple Facility Fuel Cycles was held in December, 1984. The working paper for that meeting, STR-171, "Application of Safeguards to Multiple Facility Fuel Cycles" (IAEA 1984a), described several safeguards approaches that go beyond che present facility-oriented approach in their dependence on fuel-cycle considerations. The underlying goal is to enhance the efficiency or effectiveness of IAEA Safeguards inspections, particularly for large fuel cycles. An addendum to the working paper included questions for the Consultants to answer. A key assumption in STR-171, adopted here as well, is that all safeguards approaches under discussion adhere to the guidelines in INFCIRC/153 (IAEA 1972), the prescription for agreements between the IAEA and non-nuclear-weapon States that are party to the Treaty on the Non-Proliferation of Nuclear Weapons (NPT).

Recommendations from and a general review of the meeting are summarized in STR-185, "Report of the Consultants' Meeting on the Application of Safeguards to Multiple Facility Fuel Cycles - 10-14 December 1984" (IAEA 1985).

of the alternate approaches mentioned in STR-171, the participants at the meeting only recommended further work on (1) the zone or extended material balance area (MBA) approach and approaches based on (2) the notion of randomization. The zone work recommended is further testing in the Canadian on-loadreactor (OLR) fuel cycle (Healey 1984) and preliminary study for light-waterreactor (LWR) fuel cycles. The randomization study would encompass the selection of inspection activities conducted at given facilities as well as the frequency of inspections and the facilities to be inspected within a given State fuel cycle.

In Task C.55 of the Program for Technical Assistance to IAEA Safeguards (POTAS), the zone approach was discussed theoretically and analyzed for the fresh-fuel Zone 1 of a reference LWR fuel cycle (Fishbone and Higinbotham 1986; see also de Montmollin, Higinbutham and Gupta 1985). This analysis should eventually be completed by including consideration of the irradiated fuel Zone 2 and the plutonium Zone 3.

One additional approach not from STR-171 but recommended for further study by the Consultants rests upon the uses of (3) fuel-cycle information correlations. An approach from STR-171 not recommended for further study but strongly propounded by some Consultants rests upon (4) the effect of deterrence, i.e., the likely adverse consequences of a detected diversion. Three final approaches from STR-171, neither recommended nor strongly propounded, include (5) changes in inspection goals, (6) changes in diversion assumptions, and (7) algorithms for allocating inspection effort.

St ill another approach is based upon (8) diversion-path (DP) analysis for the fuel cycle as a whole (Houck 1985). 
Brown and Gupta (1984) examined the uses of fuel-cycle information. Studies for the IAEA's Standing Advisory Group on Safeguards Implementation (SAGSI; see IAEA 1984a) encompassed changes in inspection goals outside of any fuel-cycle context and allocation algorithms within that context. Diversionpath analysis for the fuel cycle as a whole was addressed first by Nakicenkovic (1976) and elaborated subsequently by Glancy, McDaniel, and Swartz (1981).

The current IAEA inspection approach is discussed faciiity-by-facility in greatest detail in Safeguards Technical Reports (STRs). Generally speaking, this approach is closest to the facility-oriented approach outlined in Chapter II.

I.2 Meaning of Fuel-Cycle Approaches

The key aspect of a fuel-cycle approach is whether the safeguards verifications at a particular type of facility would differ from the verifications applied under the conventional facility-oriented approach because of the size or complexity of the fuel cycle in which it is located. In this context, it becomes apparent that suggestions made to date for taking into account a State's fuel cycle represent modifications of one or more individual aspects of facility-oriented safeguards approaches. Many of the proposals involving these individual aspects appear to have little if any dependence on the fuel cycle, i.e., they represent changes in assumptions and goals that are as relevant (or irrelevant) to facility-oriented approaches as to fuel-cycle approaches. For example, it had previously not been clear whether the reduced detection probabilities resulting from the application of random sampling to facilities or to inspection activities have any fuel-cycle dependence, $i . e$. , are any more applicable to a large, closed fuel cycle than to one with a single facility. The framework presented here clarifies this point.

There had previously been no integrating factor or framework from which the various aspects of any given fuel-cycle approach can be derived and on which differences in fuel cycles can impact. A framework is introduced here. Nevertheless, the adoption of a comprehensive framework that fully takes into account the characteristics of a fuel cycle is no guarantee that any fuel-cycle safeguards approaches will be significantly different from the current facilityoriented safeguards approaches. In this connection we note that the concentration of safeguards resources on the most sensitive materials in the fuel cycle (Grumm 1984 and Rosenthal 1984) shows that the IAEA has succeeded in taking certain fuel-cycle considerations into account in designing its safeguards approach. However, this and other examples do not satisfy the key aspect (underlined above) of fuel-cycle approaches used here. Thus the approaches discussed here contain fuel-cycle aspects that go beyond the aspects al ready incorporated into the present IAEA approach.

The classes of verifiable fuel-cycle information provide a promising framework for comparing these disparate approaches. With the exceptions of the deterrence approach, which deals with post-inspection matters, and the effortallocation algorithms, which deal primarily with manpower issues in the context of any approach, the approaches are classified within this framework according to the extent of verification of the information supplied to the IAEA by the State and its facilities. That is, which interfacility flows and intrafacility inventories are verified in each approach and to what degree? 
(Though the Consultants recommended against further study of the goal-change and assumption-change approaches, they are compared to the other approaches in the classification framework because they help to illustrate its utility. This pedagogical illustration should not be misinterpreted as advocacy of these approaches in opposition to the recomendations of the Consultants.)

This study, to develop a framework for the fuel-cycle concept in safeguards, is needed as a basis for possible additional United States and other contributions to a second, future IAEA Consultants' Meeting on the Application of Safeguards to Multiple Facility Fuel Cycles. Should any approaches be promising, more detailed studies in the context of actual fuel cycles could be conducted, with the possibility of implementation upon the recommendation of a still later IAEA Advisory Group Meeting.

\section{I.3 Structure of This Report}

We present three LWR fuel cycles of quite different size and complexity in Chapter II. Then we give in Chapter III a short description of both the facility-oriented safeguards approach as well as the fuel-cycle-oriented approaches to be subsequently discussed within a common framework. We describe the framework, verifiable fuel-cycle infomation, in Chapter IV. In Chapter V, we relate the different approaches to this framework by noting the safeguards verifications performed at each facility type according to each approach.

Finally, in Chapter VI, we discuss the results of the framework analysis and the insight it gives into fuel-cycle approaches to IAEA safeguards, including as well a brief and qualitative treatment of their relative effectiveness and efficiency.

References and a glossary complement the text. 


\section{REFERENCE STATE NUCLEAR FUEL CYCLES}

\section{II.1 General Remarks}

In order to demonstrate the fuel-cycle dependence or independence of various safeguards approaches, it is helpful to describe nuclear fuel cycles of differing complexity. We present here three different fuel cycles: the first containing only reactors fueled by low-enriched uranium (LEU), the second containing LEU-fueled reactors and fresh-fuel fabrication facilities, and the third a closed fuel cycle with recycled plutonium fueling some of the reactors. The facilities in each are listed in Table II-l.

For the purposes of this report, it is unnecessary to describe in detail the flows through and inventories of nuclear material at the facilities (Fishbone and Higinbotham 1984). This is done to a limited degree in Figures II-I(a), (b) and $(c)$, which depict the nuclear-material flows through the facilities in the closed fuel cycle. The characteristics of the facility types in those figures are similar to those of the facility types in the other two cycles. The main unrealistic feature of the fuel cycles, especially the second and third, is the absence of research facilities. This absence bears most importantly on the assumption-change safeguards approach (Section III.3.6). All of the fuel cycles include a multiplicity of facilities of some type to allow for at least the theoretical possibility of "borrowing" ruclear material from one facility to conceal the diversion thereof from another (see Nakicenkovic 1976 and Glancy, McDaniel, and Swartz 1981).

\section{I.2 Reactors Only}

The first reference fuel cycle contains four 1000 Mwe pressurized-water reactors (PWRs) at two sites. The aspect of this fuel cycle important to the subsequent analysis is that it encompasses no bulk-handling facilities (BHFs). LEU fresh-fuel assemblies would be imported and the spent fuel exported or indefinitely stored.

\section{II.3 Fresh-Fuel Facilities and Reactors}

Included in the second reference fuel cycle are seven 1000 MWe boilingwater reactors (BWRS) at several sites, one LEU hexafluoride-to-oxide conversion plant, and two identical fabrication plants for BWR fuel assemblies. The conversion and fabrication plants operate at capacity and have respectively onethird and one-half the capacities of the analogous facilities in Figure II-I(a). LEU hexafluoride would be imported and spent-fuel assemblies exported or indefinitely stored.

\section{II.4 A Closed Fuel Cycle}

The third fuel cycle (see Figures $I I-1(a),(b)$, and $(c)$ ) includes fourteen PWRs, seven BWRS, and racilities to convert imported LEU hexafluoride to oxide, to fabricate fresh LEU fuel assemblies for all of the reactors, to reprocess ail of the spent fuel from the reactors, yielding plutonium oxide, and to fabricate mixed-oxide (MOX) fuel for use in five PWRs and three BWRs. No attempt has been 
Table II-1

Fuel-Cycle Facilities

A. Fuel Cycle with Reactors Only

1. Four LEU-Fueled PWRs (at two sites)

B. Fuel Cycle with Reactors and Fresh-Fuel Facilities and Reactors

1. One LEU Hexafluoride-to-0xide Conversion Plant

2. Two Fabrication Plants for LEU BWR Fuel

3. Seven LEU-Fueled BWRS

c. Closed Fuel Cycle

1. One LEU Hexafluoride-to-oxide Conversion Plant

2. Two Fabrication Plants for LEU PWR Fuel

3. One Fabrication Plant for LEU BWR Fuel

4. Fourteen LEU-Fueled PWRs and BWRs

5. Seven MOX-Fueled PWRs and BWRs

6. One Reprocessing Plant

7. Two Fabrication Plants for MOX PWR Fuel

8. One Fabrication Plant for MOX BWR Fuel

made to calculate steady-state balanced flows of LEU and MOX fuels for the fuel cycle (see, e.g., the equilibrium fuel flows labeled "BWR2" in Table 8 of Appendix $V$ of OTA 1977). Thus, as configured, the facilities in this fuel cycle produce more fuel than the reactors require.

What is important is that MOX fuel is used in some of the reactors; this forces the imposition of plutonium inspection strictures on what otherwise would be areas reserved for LEU. According to the zone approach the fresh-fuel storage areas of these reactors in effect become part of the plutonium zone.

The illustration of this fuel cycle by zone in Figures $I I-1(a),(b)$, and (c) serves to delineate one reasonable choice of zone boundaries for fuel cycles of this type (see Section III.3.3.4 for the rationale). It in no way prejudices the subsequent analysis in favor of or against the zone approach to IAEA sa feguards. 


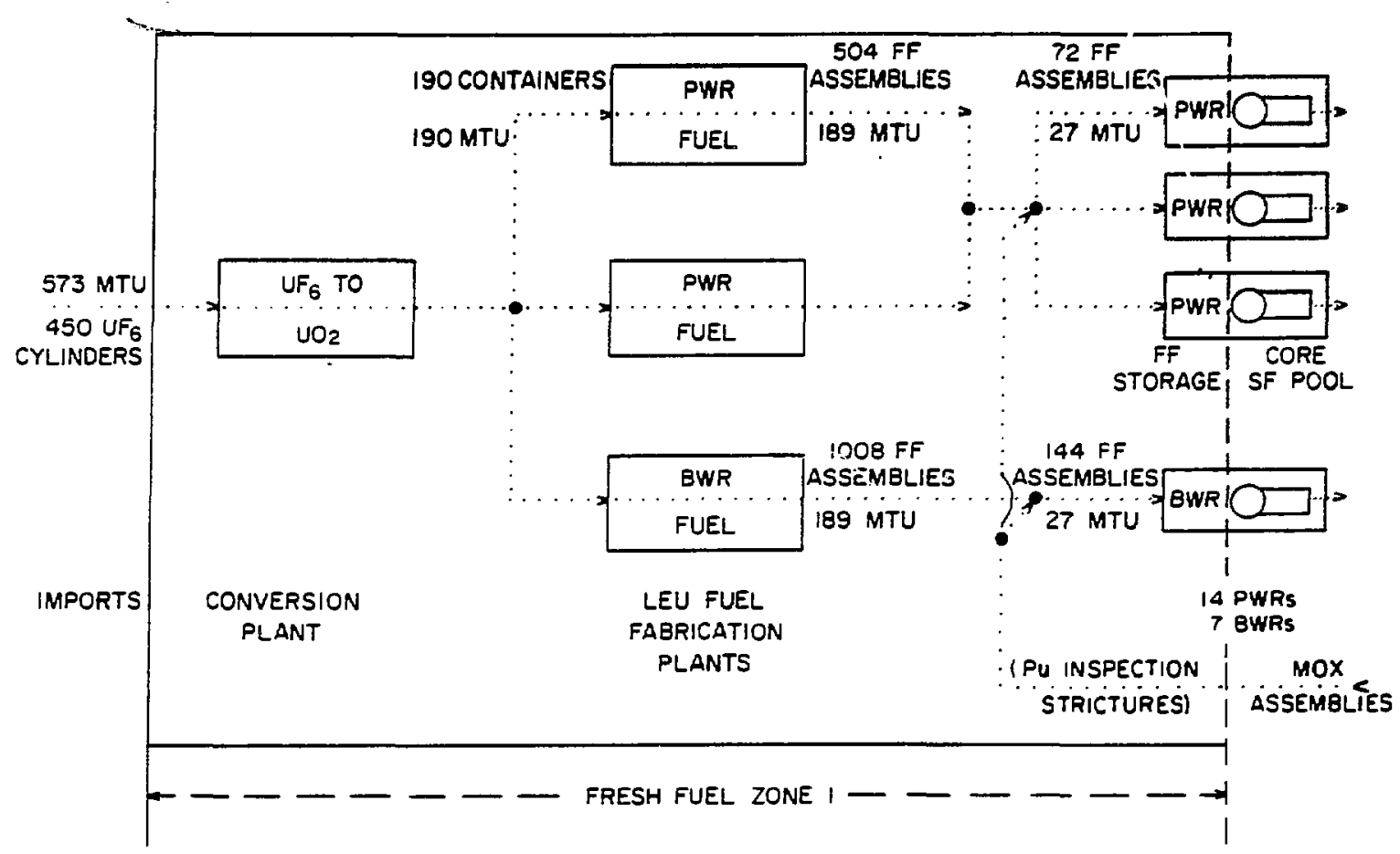

(a)

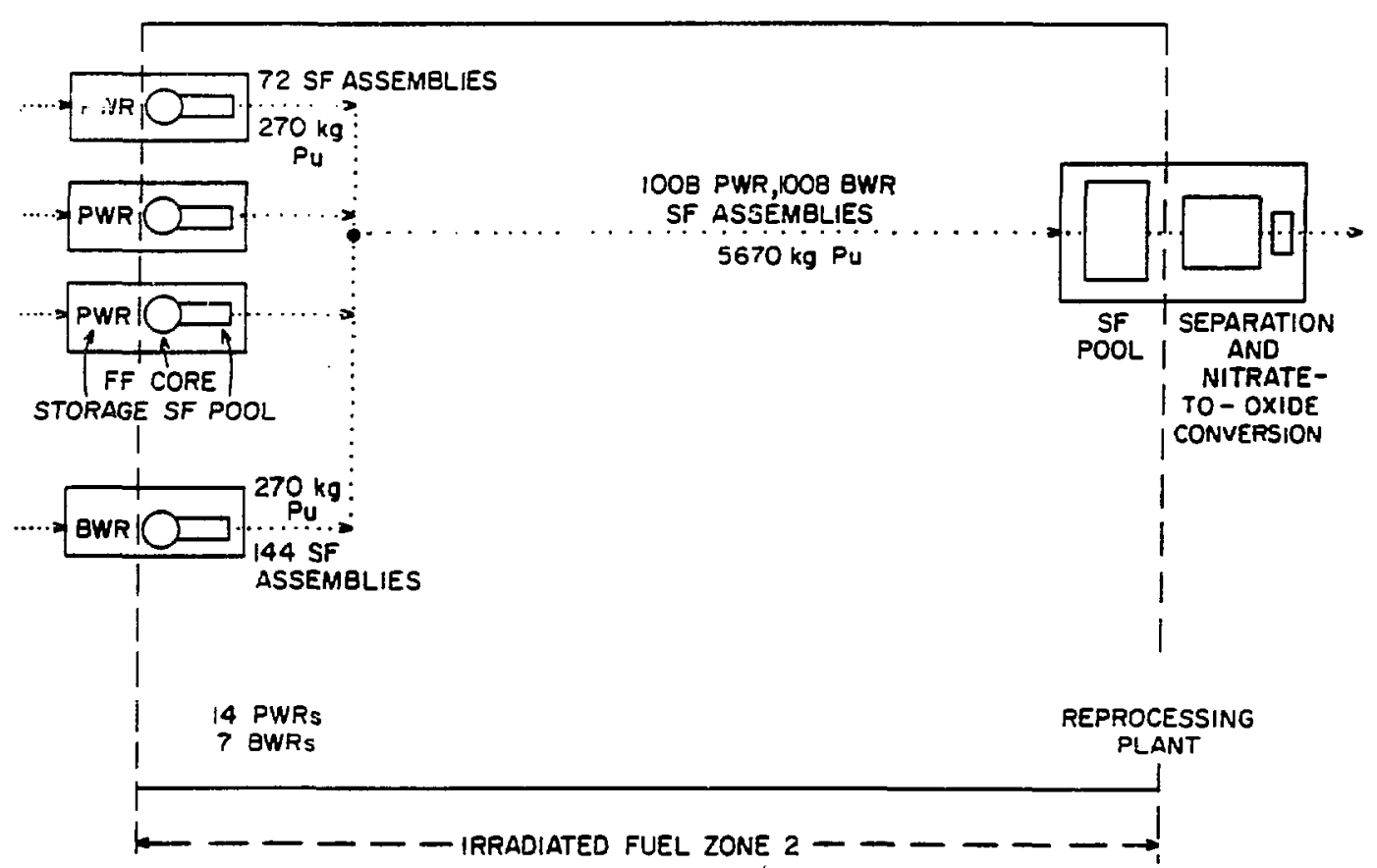

(b)

Figure II-1. Zone structure and major annual nuclear-material flows for the closed reference fuel cycle. This fuel cycle includes a separate conversion plant for $\mathrm{UF}_{6}$ to $\mathrm{UO}_{2}$. (a) Fresh Fuel Zone 1, (b) Irradiated Fuel Zone 2, and (c) Plutoni um Zone 3 . The presentation of this fuel cycle in zones in no way prejudices the analysis of safeguards approaches in favor of or against the zone approach. 


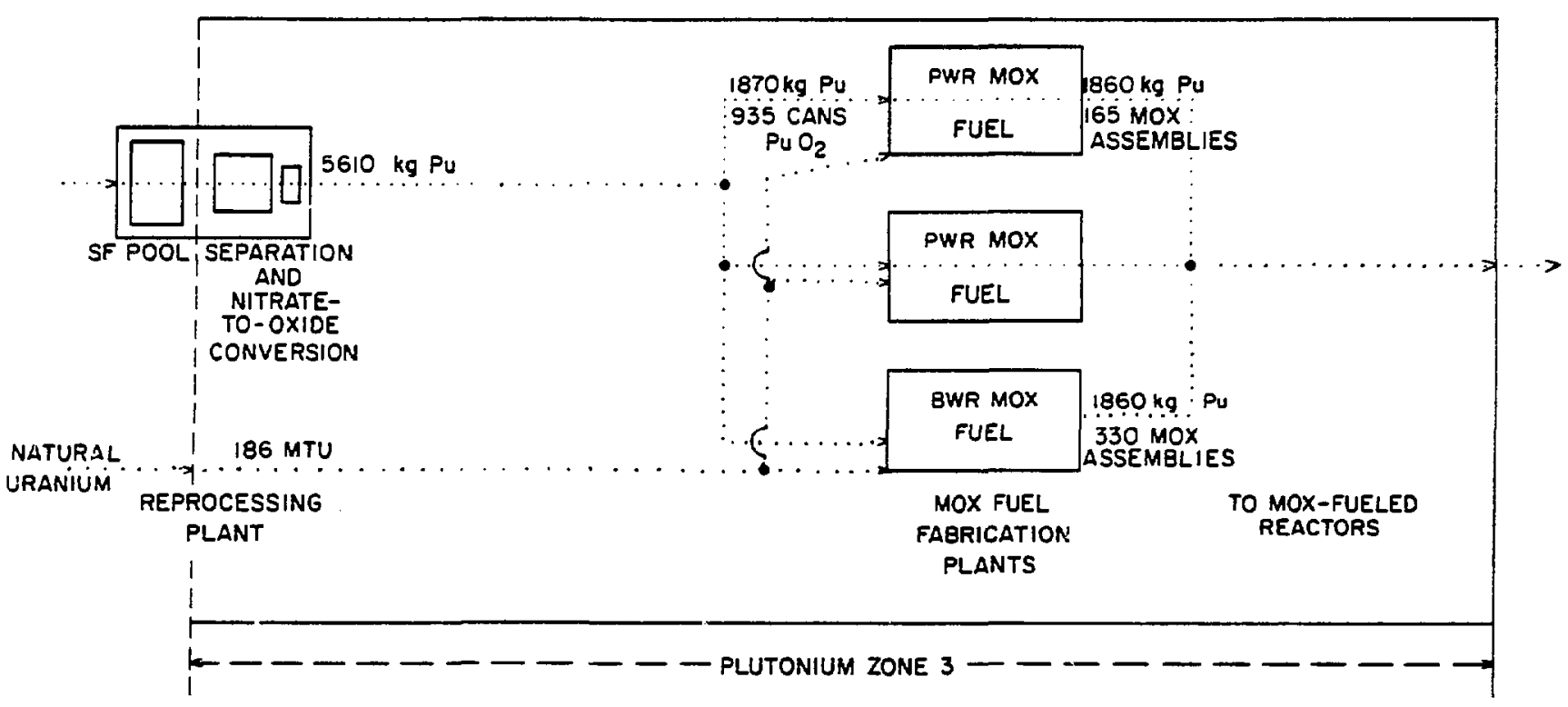

(c) 


\section{SAFEGUARDS APPROACHES}

\section{I .1 General Assumptions}

Several assumptions underlie all of the safeguards approaches under study.

First, all of the fuel cycles under consideration are in non-nuclearweapons States party to the NPT. Therefore, the document INFCIRC/153 gives the guidelines for the safeguards agreements between these States and the IAEA. The approaches must adhere to these guidelines. In particular, all nuclear materials in the fuel cycles are subject to IAEA safeguards verifications and there are no unsafeguarded peaceful nuclear facilities.

Second, the IAEA reports annually on its safeguards verification activities. We therefore assume that an annual physical inventory verification (PIV) of all nuclear material in the fuel cycles must be included in any approach considered; the consequent annual PIV at each facility shall not be subject to randomization over facilities (see Section III.3.4.4). It would be possible to relax this assumption and perform the analysis accordingly. Other verifications requiring routine inspections shall be included as the particular approach requires.

Third, ad hoc inspections to verify design information and the initial inventory of nuclear material and special inspections to verify the information contained in special reports shall be part of all approaches. Since these verification activities cannot serve to distinguish the approaches from one another, they need no further discussion in this report.

Fourth, collusion among different States to carry out or conceal a diversion is assumed not to occur. On the other other hand, a low hut nonzero probability of diversion anywhere is assumed, so that safeguards verifications at each facility must take this into account. Unless otherwise specified (see Section III.3.6), the possibility of undeclared facilities, undeclared nuclear materials, or unknown technical skills is not excluded.

Fifth, material accountancy (MA) supplemented by containment and surveillance (C/S) is the basic safeguards measure for all approaches. Thus all rou'tine accounting reports specified in the document INFCIRC/153 would be submitted for each facility containing nuclear material. In particular, this allows the IAEA to compare shipper and receiver accounts for each nuclear-material transfer between facilities and maintain a book inventory of the nuclear material at each. What distinguishes several of the approaches is the degree of verification of these routine accounting reports.

Sixth, no new technology is permitted for any of the safeguards approaches, i.e., all proposed verification activities must have been demonstrated.

Seventh, only technical factors may be exploited to obtain fuel-cycle-dependent verifications; political factors are not considered. Thus, similar fuel cycles in different States must be similarly safeguarded.

Eighth, certain inspection activities involving nuclear-material flows across zone boundaries (see Fig. 1) within the fuel cycle are part of all of the inspection approaches. These include verifications of enrichment-plant (not 
specifically in the fuel cycles considered) product, of LWR refuelling (fresh and spent fuel transfers), and of reprocessing-plant. dissolver accountability batches.

Ninth, what we present here for I ater comparison are theoretical safeguards inspection approaches, of which the facility-oriented approach based on facility-specific published reports prepared by or for the IAEA is presumably closest to current IAEA objectives. It, is beyond the scope of this report to specify actual IAEA practice as limited by manpower, equipment, and other constraints.

Tenth and finally, concerning effectiveness and the perceived credibility of IAEA safeguards, care would be needed to explain a change from a facilityoriented approach encompassing input and output flow verifications at all facilities, BHFs especially, to any approach that does not provide for verified MA at all facilities.

\section{III.2. The Facility-Oriented Approach}

\section{III.2.1 The Fundamental Role of Materials Accountancy}

According to the conventional, facility-oriented approach, MA applied to each MBA within each facility is the fundamentzl safeguards technique (see Paragraph 29 of INFCIRC/153). Thus each component of the material balance as given in the material-balance equation for MUF (material unaccounted for) should be verified by the IAEA for each MBA. The equation for a single material--balance period is (IAEA 1980)

$$
\text { MUF }=P B+X-Y-P E,
$$

where $P B$ is the beginning pnysical inventory, $X$ is the sum of increases and $Y$ is the sum of decreases to inventory, and PE is the ending physical inventory.

One test of MA that can be applied given sufficient data is the comparison of the verified value of MUF (or related statistics) to its estimated or measured standard deviation and to the appropriate accountancy goal. Absent diversion, MUF should rarely differ significantly or inexplicably from zero in the sense of statistical hypothesis testing. If there were such a nonzero MUF, an investigation by the IAEA would occur. Other types of anomalies would also lead to investigations.

\section{2.2 Physical-Inventory Verifications (PIVS)}

In order to verify the material bal ance represented by equation (III-1), the IAEA must verify the beginning and ending inventories PB and PE. Such verifications occur during annual or semiannual plant shutdowns for physical-inven-tory takings (PITS) at BHFs, ideally during refueling at LWRs, and during operá$t i$ on for on-load reactors (OLRs). For LWRS, the PIVs occur annually even if core reloadings do not take place that ofien, in which case the fresh-fuel and spent-fuel inventories are verified, and the core seal as well if it is possible to do so while the reactor is operating. Also, interim inventory verifications are performed monthly for BHFs handling plutonium.

In verifying the inventory of nuclear material at facilities, inspectors collect data that can help rule out diversions concealed by "borrowing" substi- 
tute nuclear material from other facilities or from transit (see Appendix $E$ of Fishbone and Higinbotham 1986 for a summary). Specific measures to preclude such concealments include item identification, $C / S$ measures, and simultaneous inspections at related facilities. This particular diversion scenario exists for any safeguards approach and dealing with it is an objective of the IAEA s.lfeguards approach in use.

\section{III.2.3 Flow-Measurement Verification}

The second aspect of the verification of equation (III-1) is verification of the additions to and subtractions from inventory, $X$ and $Y$, the chief contributors to which are the feed entering and product leaving the facility under consideration. In the facility approach, each flow stratum should be verified either by direct measurement or by identification of a sealed and previously measured item. The statistical sampling plans for verification of each flow depends on the amount of nuclear material expected in each flow, flow-measurement uncertainties, the goal quantity, desired probability of detection of a missing goal quantity, and desired false-alarm probability. The last three parameters, indicative of performance, would generally be the same from facility to facility. (Analogous considerations apply to the verification of inventories. Ideally, sampling plans are derived from unified inventory and flow data.) C/S devices at flow key measurement points (KMPs) and natural facility containments may help to ensure the completeness of flow verification.

As defined here and as analyzed in Chapter $V$, the facility approach for a series of facilities would involve double flow verifications, $i . e .$, at the shipper's and at the receiver's facility. In practice, carrying out such double flow verifications would require much coordination.

\section{III.2.4 Fuel-Cycle Aspects of the Facility-Oriented Approach}

Several IAEA safeguards fuel-cycle features other than the one emphasized in this report (Section I.2) are explicitly and implicitly incorporated into the present approach (Grumm 1984).

First, safeguards activities are heavily concentrated on facilities with the most sensitive nuclear materials (Rosenthal 1984) and with the capability to process such materials. This results both from the use of the concept of significant quantities (SQs) of nuclear material in designing sampling plans and from the need to satisfy timeliness goals (IAEA 1980).

Second, since all nuclear materials in all peaceful nuclear facilities are under safeguards in States party to the NPT, the safeguards approaches at facilities in such States can differ from those at similar facilities in States not party to the NPT. In the former case, correlations involving the nuclear-material flows among facilities can be relied upon to provide safeguards verification information. In particular, shipper-receiver comparisons take explicit account of the orderly flows of nuclear material between fuel-cycle facilities, and, by serving as a check on the transportation link, demonstrate that the safeguards approach covers more than just facilities. In practice, the degree to which such correlations distinguish NPT safeguards from non-NDT safeguards is unclear since the main reporting done by the IAEA is facility-based.

The approaches studied in this report go beyond these features by incorporating the fuel-cycle dependence emphasized in Section I.?. 


\section{III.2.5 Facility-Oriented Practical Considerations}

Chiefly, the facility-oriented safeguards approach requires frequent presence of IAEA inspectors at BHFs especially. This means enough visits to verify flow measurements, with possible impediment to facility operations. For LEIJ fresh-fuel facilities, generally lacking natural facility containment and without material having stringent timeline; goals, procedural arrangements with facility operators would probably be required to all ow the inspectors to verify all flows. These procedures, chiefly holding materials for measurement, may be in conflict with commercial requirements. In the absence of such procedures and of near-continuous inspection, only stocks of feed and product that happen to be present would be available for inspection.

For each facility type in question, detailed lists of inspection activities are available in reports done by or for the IAEA. These include reports for LWRs (Kaniewski 1983), LEU conversion and fuel-fabrication plants (Thorstensen and Thorne 1981 and IAEA 1984b), reprocessing plants (Sukhoruchkin 1979, Lovett, Ikawa, and Tsutsumi 1983, and Higinbotham and Fishbone 1985) and MOX fabrication plants (Bahm, Shea, and Tolchenkov 1980 and Keisch and Sanborn 1984).

Because of the absence of a method for measuring the nuclear-material content of fuel assemblies, the existing safeguards approach for LEU fabrication plants has not been based on full. flow verification (Thorstensen and Thorne 1981). We assume in this report that the neutron-collar method (Menlove, Keddar, and Beets 1981 and Menlove and Keddar 1982) suffices for this measurement and for the analogous measurement at MOX fabrication plants (Menlove 1982).

\section{II .3 Fuel-Cycle Approaches}

\section{III.3.1 Information-Correlation Approach}

The facility-oriented safeguards approach based on INFCIRC/153 was designed to exploit the highly organized fuel flows in a nuclear fuel cycle. However, information about these highly correlated flows is built into the present, facility-oriented safeguards approach only to a limited degree. The information-correlation approach (IAEA 1985) would, "...make use of the entirety of the information available to..." the Agency "...with the aim of improving the effectiveness and efficiency of inspections..." Others have promoted this approach in more detailed papers (Bennett et al. 1971, Gupta et al. 1972, and Brown and Gupta 1984). In many cases, specific types of additional information or specific correlation methods seem to be most useful as redundant checks or technical cross-checks on standard MA data. Examples of such information are fuel isotopic composition, fuel-assembly shipping schedules and reactor power records. Examples of correlation methods are the gravimetric method, isotopic correlation techniques, and isotopic transient analysis. In any event, there does not yet exist any comprehensive study incorporating such information correlations into a safeguards approach supportive of IAEA safeguards conclusions.

For the purposes of the present study, we illustrate only one obvious conclusion of the information-correlation approach. Since nuclear material shipped by any given facility is received by a second facility for use or subsequent processing and might then be shipped to a third facility, verification of 
the flows to and from the second facility could be performed by measurement verifications at the first and third facilities or, in the absence of collusion, simply by comparison of the two sets of shipper/receiver (S/R) data. Thus, this illustration of the information-correlation approach consists of verification on a facility-oriented basis with the el imination of redundant (Bennett et al. 1971) flow verifications at BHFs. This might al so be termed a "practical"

facility-orjented approach. The degree to wich actual verification procedures at a particular facility could be replaced by verification information generated el sewhere would depend on the flow patterns among the facilities in the fuel cycle, the sensitivity of the nuclear material handled, the residence time of the material at the facility, and assumptions about collusion anong the facility operators to conceal diversions. There could al so be timel iness difficulties in acquiring receiver data from the third facility (see above) for determination of the material balance at the second for a given material-balance period.

\section{III.3.2 Diversion-Path (DP) Analysis for the Fuel Cycle as a Whole}

DP analysis is the miethod of specifying in great detail both the ways of diverting nuclear material from a nuclear facility and of concealing the diversion (Goodwin, Schleter, and Maltese 1978). Often this is carried out for a single facility to permit assessment of the effectiveness of safeguards measures. This has been done for LWRs (Sanborn 1981, 1984a,b), an LEU fuel-fabrication plant (Swartz, Glancy, and McDaniel 1980), a Mox fuel-fabrication plant (Keisch and Sanborn 1984), and a spent-fuel reprocessing plant (Higinbotham and Fishbone 1985).

Application of DP analysis to an entire fuel cycle means allowing the diversion paths and concealment schemes to involve more than one facility as well as transit between facilities (Nakjcenkovic 1976 and Glancy, McDaniel, and Swartz 1981). Examples of such concealments are, first, borrowing materjal to conceal diversions and, second, in the absence of flow verification, the shifting of discrepancies in the material balance from a well-measured stratum in one facility to a poorly measured one in another by data falsification. These points being recognized, all inspection approaches must take them into account. For example, both the facility-oriented approach (Section III.2) and the zorie approach (Section III.3.3) include measures to counter the first concealment. on the other hand, the zone approach defined here explicitly excludes flow verifications to counter the second concealment.

The safeguards approach based on DP analysis for the fuel cycle as a whole is the set of inspection activities that optimally covers the DPS posited for the conventional facility-oriented approach (Houck 1985). Optimality means the most efficient use of inspection resources to cover the given set of ips (a desirable feature for any safeguards approach). Given that this approach stili relies on MA as the basic safeguards measure, the search for the optimal set of inspection activities and the facilities at which to conduct them involves a detailed study of the resource requirements for individual activities; such a search goes beyond the purview of the present report. If the accountancy is facility-oriented, then this approach would generally be similar to the aforementioned illustration of the information-correlation approach (Section III.3.1), with single flow verifications. (It would further be possible to supplement this approach with elements of the zone and randomization approaches.) For this reason and because this approach of DP analysis for the fuel cycle as a whole depends for its characterization on a detailed study of ways to cover DPS, it is not explicitly compared to the other approaches in Chapter $V$. 


\section{II .3 .3 The Zone Approach}

\section{III.3.3.1 General Description}

According to the zone or extended-MBA approach used here, MA is applied to a collection of facilities or parts thereof in a fuel cycle, instead of to a single facility or part thereof. (Bennett et al. 1974; IAEA 1984a; Healey 1984; Brown and Gupta 1984; de Montmollin, Higinbotham and Gupta 1985; and Fishbone and Higinbotham 1986.) The essence of the zone approach is then the elimination of measurement verifications of interfacility, intrazone nuclear-material flows and the determination of verified inventories for all of the nuclear material within the zone for the beginning and end of the zone material-balance period. Since, as the number of facilities and fuel-cycle complexity increase, the number of intrazone flows also tends to increase, this approach shows promise for promoting safeguards efficiency (in the sense of effort expended per facility) as fuel-cycle complexity increases.

Subject to the eighth assumption in Section III.1, interzone flows, however, could be verified at the facilities within the zone or at facilities outside the zone, conceivably in another State (fourth assumption) (de Montmollin, Higinbotham, and Gupta 1985 and Fi shbone and Higinbotham 1986).

An important question is whether a zone approach would merely be a verification technique for the IAEA within the existing MBA structure or whether the MBA structure itself would be extended to correspond to the zones (see IAEA 1984a, Appendix A of Fishbone and Higinbotham 1986, and Attachment $D$ of IAEA 1985.) In the former case, assumed here, the existing Subsidiary Arrangements and $F$ aci Tity Attachments that specify State reporting requirements would continue to apply and the IAEA could still maintain book inventories for all facilities within a zone based on frequent interzone and intrazone inventory change reports (ICRS) as well as annual material balance reports (MBRs). In the latter case, Subsidiary Arrangements and Facility Attachments would require revision and the IAEA would be able to maintain facility book inventories based only on annual MBRs and interzone ICRs. However, the absence of intrazone ICRs lacks significance for facilities for which timeliness requirements dictate frequent interim inventory verifications.

\section{3.3.2 Zone Materials Accountancy}

The differing MA aspects of the facility and zone approaches are illustrated by specifying the material-balance equation (III-1) for two plants within a zone, with one supplying the other. An example is a conversion plant (subscript c) supplying a fabrication plant (subscript $f$ ):

and

$$
\text { MUF }_{C}=\left(P B_{C}+A_{c}\right)+F_{c}-P_{c}-\left(P E_{c}+S_{c}\right)
$$

$$
M U F_{f}=\left(P B_{f}+A_{f}\right)+F_{f}-P_{f}-\left(P E_{f}+S_{f}\right)
$$

Here $F$ is the feed; $P$ is the product; and $A$ and $S$ are respectively the other additions to and subtractions from inventory, e.g., recycled scrap and waste. (The actual fresh-fuel zones under study iriclude fresh-fuel stores at reactors as well; see Fig. II-1(a).) 
According to the zone approach, the flow of uranium oxide from the conversion plant to the fabrication plant is not verified at al 1 , though all other flows entering or leaving either plant would be. (This is equivalent to treating tre t:HO plants as a single plant either with one MBA or divided into two MBAs for which the inter-MBA flow $P_{c}=F_{f}$ is not verified. Scrap recycle flows would similarly not be verified.) At the end of the materialbalance period, there would then be a single verifiable MUF for the entire zone, namely,

$$
\begin{aligned}
M_{z} & =M U F_{c}+M U F_{f} \\
& =\left(P B_{c}+P B_{f}+A_{c}+A_{f}\right)+F_{c}-P_{f}-\left(P E_{c}+P E_{f}+S_{c}+S_{f}\right)
\end{aligned}
$$

Interpretation of the MUF for the zone would be based on a comparison with an accountancy goal for the zone and would be subject to statistical and measurement uncertainties. A reasonable approach to sampling plans for zone PIVs would be to choose them for each facility to coincide with the PIV sampling plan that would obtain according to the facility-oriented approach.

Since MA would be verified for the zone material balance--equation (III-3)--but not for the material balance for each facility--equations (III-2)-the particular facility at which there is a nuclear-material discrepancy could not in theory be determined from information verified by the IAEA. In practice, facility conclusions could be drawn based on partially verified information. For example, facility accountancy goals could be computed based on operator measurement uncertainties for all components of the facility MUF equations but on operator-inspector differences only for the inventory components: the inspector would accept the operators' values for intrazone-flow measurements. However, late ICRs could delay the determination of intrazone facility material balances for any given material-balance period if $S / R$ comparisons are employed for flow verification.

Another point is that for the LEU and Pu zones (see Section III.3.3.4), zone MA is likely to be inventory-dominated over one-year periods, whereas facility MA is likely to be flow-dominated. Given well-founded sampling plans and proper implementation of zone PIVs and interzone flow verification, this difference should not affect zone MA negatively with respect to facility MA.

\section{III.3.3.3 Zone Physical-Inventory Verifications}

A determination of a zone MUF requires that the physical inventory of the zone be verifiably determined at the beginning and end of the materialbalance period. A conceptually simple way to do this is by carrying out simultaneous (or nearly simultaneous; see Section 4.4 .1 .3 of IAEA 1984a) PIVs at all the facilities within the zone. An additional benefit of simultaneous PIVs is the prevention of concealments of diversions of nuclear material at one facility by "borrowing" substitute material from another. If simultaneous PIVs were not conducted, book inventories for the beginning and end of the material-balance period could be inferred from PIVs at other times by making accounting adjustments on the basis of reported flows (de Montmollin, Higinbotham, and Gupta 1985). The problem with this method is that intrazone flows would not be veri- 
fied; thus, the inventories upon which the zone MUF is based would not be completely verified. The importance of gaps in the verified zone inventory due to a lack of simultaneity in facility PIVs depends on the amount of unsealed material (generally, bulk material in process in the facilities), its safeguards significance (e.g., Zone 1 LEU versus Zone $3 \mathrm{Pu}$ ), the plausibility of DPs involving this material, and the timeliness and patterns of information about the nuclear-material flows (de Montmollin 1985).

Should simultaneous PIVs based on simultaneous PITs he done, they must extend over a time sufficiently long to allow all the material in transit between the facilities in the zone to be received for verification. The requirement is similar to the "simultaneity" required when conducting a PIV at a single facility: all material there or in transit thereto should be verified once to assure the validity of the PIV.

For a fresh-fuel zone, near-simultaneity might mean that inspections could begin literally simultaneously at the fabrication plants and take approximately a week. Thereafter, one inspector could remain at each fabrication plant to ensure that the inventory is not altered while other members of the teams proceed to the PWRs and any conversion facility supplying the fabrication plants and then to the BWRs. Furthermore, since even nearly simultaneous core-opening PIVs at LWRs are wholly impractical, the verifications there would often consist of interim inspections during which only the fresh-fuel and spent-fuel inventories and, if accessible, the core seal are verified. of course only the fresh fuel is within the fresh-fuel zone.

\section{I.3.3.4 The Choice of Zones}

The reason that a closed fuel cycle is subdivided into three zones is that the three zones respectively encompass three classes of nuclear material with different safeguards significance: unirradiated LEU, irradiated fuel assemblies, and bulk unirradiated plutonium. Zone boundaries for fuel cycles in general would be at enrichment plants, reactors, and reprocessing plants. According to this principle and the necessity for good flow-measurement verification, the boundary between the irradiated-fuel zone and the plutonium zone must be at the accountability tank of the reprocessing plant because flow measurements there permit the verification of the amount of plutonium in the fuel cycle at the first time it becomes accessible. Analogously, the boundary between the unirradiated-LEU zone and the irradiated-fuel zone is at the reactor cores. The choice of three zones also leads to a set of flow verifications equivalent to the "primary" verifications identified by Bennett et al. (1971) in an important early study of verification redundancy (see the eighth assumption of Section III.1). This same principle would clearly lead to fewer zones in fuel cycles with less complexity. Nevertheless, two zones would be necessary for States with reactors only, since there are two material classes and a verification is necessary of what goes into the reactor core.

The notion of zones is useful even without the verification structures discussed here. For example, it offers a way to compare the relative intensities of safeguards inspection effort applied to the different nuclear materials characteristic of the three zones of a closed fuel cycle. Thereby effort allocations can be understood according to a comnon measure (de Montmollin, Higinbotham, and Gupta 1985). 


\section{III.3.3.5 Zone-Approach Practical Considerations}

The likely additional requirement for the zone approach is nearly simultaneous PIVS, which in turn depend on nearly simultaneous PITs, or a functional equivalent as described above. Implementation of this approach by the IAEA would require increased cooperation by facility operators and the State. But the increased uniformity of inspection practice necessitated by such a regimen suggests that it could be a benefit rather than an imposition (see Section 4.4 .1 of IAEA 1984a).

Conducting nearly simultaneous PIVs at all facilities within a fuel-cycle zone would force the IAEA to concentrate a large number of inspectors and much equipment in one State nearly simultaneously, leading to questions regarding their availability. An important mitigating circumstance is the Jiversity of fuel-assembly types and reactor types. Assurance that all material is accounted for would apparently only require nearly simultaneous PIVs at facilities handling interchangeable materials. For example, BWRs and PWRs need not undergo simultaneous verifications since their fuel assemblies are not interchangeable; sequential PIVs would be satisfactory.

For the fresh-fuel zone of an LWR fuel cycle, the zone approach might be implemented by having the quantitative neutron-collar verification of the nuclear-material content of fuel assemblies take place at the reactors rather than at the fabrication plants. This would pose a significant cost and have a significant effect on fuel operations at reactors, where careful measurements of the nuclear-material content of fuel are not now done. An alternative would be a seal verification at reactors and collar measurement at the fabrication plants.

Other practical effects would be that fewer inspection resources would be required at some facilities for flow verifications. As a consequence, tha burden of inspections on facility operations would be reduced. Though inspection-effort savings would be great in the fresh-fuel zone (Fishbone and Higinbotham 1986), thay would be much less in the plutonium zone where timeliness dictates frequent interim inventory verifications.

\section{III.3.4 Randomization}

III.3.4.1. General Remarks

The safeguards inspections carried out by the IAEA consist of diverse activities. Given both the desirability of more activities or more inspections and the reality of resource constraints, randomization in situations where it is not now applied constitutes a potentially efficient method for maintaining or increasing effectiveness. For a given level of inspection effort, randomization aliows more DPs to be covered by inspection activities, though with a reduced detection probability for each path. Both the unpredictability and the wider coverage have value. Also effort savings at some facilities resulting from randomization could allow effort enhancements at others.

Random selection is already a part of safeguards practice: neasurement verification--whether attributes or variables--is typically carried out for a fraction of the batches or items of nuclear material in a plant. Complete verification is rare. A practical problem for some levels of randonization is access to the complete population subject to randomization. 
With respect to inspection activities at a single facility, randomization means that the IAEA inspectors would be prepared to carry out many activities but would only carry out some (Ulvila and Brown 1982 and Ulvila 1984). Probably the group of activities subject to random selection would be supplementary to a group that is always carried out. For example, audit reviews would probably always be done, while the decision to observe the Cerenkov gl ow a round spent fuel assemblies in reactor pools could be subject to randomization. If it were done, the assemblies to be studied would themselves be chosen on the basis of random sampling.

A 1 imiting case of randomization over activities would be to eliminate entire interim inspections on a random basis and thereby reduce the like1 ihood that certain anomalies might be detected at the facilities so affected.

\section{III.3.4.3 Over Inspection Timing}

Another notion is that of varying the scheduling of inspections in a random way. This results in unannounced inspections (Glancy, McDaniel, and Swartz 1981), which involve practical difficulties beyond those associated with the random fulfillment of a scheduled inspection. These difficulties include visa acquisition for inspectors and the need for plant-operator planning for and cooperation in inspection activities, especially to have materials available for inspection. Since these all require time, meaningful unannounced inspections do not seem feasible as a routine measure.

\section{III.3.4.4 Over Facilities}

With respect to a collection of facilities of a given type, randomization means that IAEA inspectors would be scheduled to carry out inspections at all of them, not necessarily simultaneously, but would only do them at some fraction (Bennett 1983 and Petit 1984) of scheduled visits; the omitted facilities must not be known in advance to the subject State and facilities. Also, the facility operators must make their nuclear-material declarations before the selection of facilities to be inspected becomes known (Gordon and Sanborn 1984). Given these conditions, facility randomization could mean, for example, that IAEA inspectors would only appear at fuel fabrication facilities to verify flows some fraction of the number of times they have the permission to do so. This would not conflict with existing timeliness goals, as might randomized interim inventory verifications at reactors with respect to spent fuel.

\section{III.3.4.5 Over States}

There is further the possibility of extending the notion of randomization over facilities to situations where the facilities are not in the same State. If, for example, several States with only a fow reactors each are subject to collective randomization, then it would be possible for all of the facilities within one State to "escape" inspections during a reporting periodby chance. However, since these facilities would have been subject to inspection, it would be justifiable to explain ex post facto that inspection goals were met in the State though none of its facilities had been inspected. 
A key objection to this notion of randomization over States is that the objective of NPT safeguards is to draw inferences about states--not to worlawide populations of facilities.

\section{3.4.6 Randomization-Approach Summary}

What are compared in the Chapter $V$ analyses of safeguards ap-proaches are two randomization approaches: over activities and over facilities. Randomization over States and over inspection timing are not considered (IAEA 1985).

Randomization over activities is presented in two variants. According to the first, the inspection effort is lower than in the facilityoriented approach; the same number of DPS is covered but at a lower probability of detection for each compared to the probability in the facility-oriented approach. According to the second, the effort is equal to that in the facilityoriented approach but there is a change in the intensities of verification activities to put more emphasis on some DPs and less on others.

\section{III.3.5 Inspection-Goal Relaxation}

In work for the IAEA's Standing Advisory Group on Safeguards Implementation (SAGSI; see IAEA 1984a), the changes--increases or decreases--were calculated in required inspection effort at various facility types due to quantitative changes in safeguards goals. Nuclear-material goal quantities, probabilities of detection for simple diversion scenarios, anu timeliness criteria were varied. The inspector effort required to carry out the needed inspection activities for both a model LWR fuel cycle and a model OLR fuel cycle was then determined.

Of key importance here is that the goals were varied by facility without regard to fuel-cycle complexity. Thus, the calculations from that earlier work of the effects on inspector effect at each facility type are directly relevant" to fuel-cycle approaches only if the goal changes inducing those effects depend on the fuel cycle (IAEA 1984a). One example of a quantitative, fuel-cycledeperident goal change would be to allow the probability of detection in sampling calculations to decrease as a function of the fraction of a State's electric power generated by nuclear reactors. In a sense, ihis example incorporates deterrence notions (Attachment A of IAEA 1985). A second quantitative change. would be to allow a longer time between spent-fuel verifications in States without a reprocessing facility thain in States with one (IAEA 1984a).

\section{III.3.6 Diversion-Assumption Changes}

A number of assumptions concerning diversions and concealments lie behind the IAEA's planning for safeguards verifications (Grumm 1983c; See Section III.1). Of course a fundamental assumption is that the possibility of diversion cannot be rejected. From this flows the regimen for specific safeguards activities at specific facilities. 
One possible altered assumption is that there is negligible risk of diversion of LEU and spent fuel. This assumption change can be invested with fuel-cycle dependence by associating it with the absence of reprocessing and enrichment capabilities.

Another assumption subject to fuel-cycle-dependent change is that the threat of diversion is the same at all facilities. This is amenable to analysis by Bayesian consideration of relative a priori diversion probabilities (see Annex 4 of IAEA 1984a) or by weighting the values of the SQs of different nuclear materials differently and thereby affecting inspection activities through sampling requirements. The different $S Q$ values for different material types already do this even though these values were introduced for other reasons.

Since the effect of any particular assumption change might be different in a comparison of the fuel-cycle dependence of different safeguards approaches, we shall for definiteness consider a single specific assumption change: DPs shall be excluded from consideration if they require facilities of a type not known to exist in the State. In particular, given that immediate nuclear-weapon production is the aim, this means that diversion of spent fuel would require the known existence of a reprocessing plant or hot cell to be credible. Then diverted spent fuel could be reprocessed in a clandestine plant, since the State would have demonstrated the ability to build one. Analogously diversion of fresh fuel would require the known existence of an enrichment plant or reprocessing plant to be credible (see Annex 4 of IAEA 1984a and, for a different view, Weinstock 1982). Then, diverted fresh fuel could either be enriched or be irradiated and reprocessed in clandestine facilities of a type the State would have demonstrated the ability to build.

The facility-oriented approach is the "default" approach should the conditions for the change in assumption not hold.

We recognize that the assumption change chosen for illustration is by no means one that would be universally accepted. 


\section{INFORMATION AS THE FRAMEWORK FOR COMPARING SAFEGUARDS APPROACHES}

IV.1 What Does the IAEA Verify Routinely?

For a State party to the NPT and therefore subject to full-scope safeguards, what the IAEA does is to apply safeguards "...on all source or special fissionable material in all peaceful nuclear activities within the territory of such State, under its jurisdiction, or carried out under its control anywhere" (expressed in Article III; see Barton and Weiler 1976). The motive for these safeguards is to verify fulfillment of part of the State's obligations under the NPT, namely, the obligation not to divert "...nuclear energy from peaceful uses to nuclear weapons or other nuclear explosive devices..." (Article III).

This general verification task is carried out by means of safeguards inspections of a nature codified in an agreement between each State or group of States and the IAEA, the specification for which agreement is INFCIRC/153 (IAEA 1972). The specific goals of routine inspections are specified in Paragraph 72:

(a) Verify that reports are consistent with records;

(b) Verify the location, identity, quantity and composition of all nuclear material subject to safeguards under the Agreement; and

(c) Verify information on the possible causes of material unaccounted for, shipper/receiver differences and uncertainties in the book inventcry.

That the verifications should be "timely" follows from the general objective of "timely detection" in Paragraph 28.

The accounting information is supplied to the IAEA in regular reports about the nuclear materials in all peaceful activities within each State. This information comes from nuclear facilities through each State. The individual types of reports are discussed below.

Two caveats are important. First, notice of all of the inventory changes to be verified during facility inspections may not have been received by the IAEA in ICRs prior to the inspections. Since the relevant reports will be received, they need not be considered special in the subsequent exposition. A second point concerns goals and is more problematic. Giving assurance that diversion has not occurred when it actually has not is operationally the routine goal of IAEA verifications. The ability to provide such assurance results from a high probability of detecting diversion should it occur. However, while it is relatively straightforward though perhaps tedious to verify the inventory of nuclear materials declared by the State to be under safeguards, this capability has technical limits. For this reason C/S measures supplement $M A$ as auxiliary safeguards inspections measures. The information therefrom derived gives credence to the completeness of quantitatively verified accounting inforination in regular reports, but is in and of itself not regular accounting information. Other C/S functions are to eliminate the need for flow or inventory measurement reverifications by maintaining the continuity of knowledge, e.g., by sealing items or observing. In this sense, $C / S$ measures are surrogates for accounting verifications. Finally, one last $\mathrm{C} / \mathrm{S}$ function is to prevent the use of "borrowed" materials to conceal diversions by uniquely identifying items. 
Since $\mathrm{C} / \mathrm{S}$ measures are associated with or auxiliary to accounting verifications, consideration of these measures does not help distinguish among the safeguards approaches more than does consideration of just the underlying accounting verifications. Hence $C / S$ does not require explicit treatment in the definition of a framework for comparing safeguards approaches. (For a discussion of the MA-C/S interface from a different viewpoint, see Markin, Gutmacher, and Shipley 1983.) This point notwithstanding, the frequency of inspections at reactors and certain other storage facilities is determined primarily by the need ior timely interpretation of the information from and the servicing of surveillance cameras.

IV.2 Verifiable Information Classes Available from Generic Inspection Types

Given the caveats in the previous section, three classes of information about a facility are relevant to the material balance there and are verifiable there or elsewhere (see Beetle 1985 for a more analytical approach).

\section{IV.2.1, Shipper and Receiver Data}

Nuclear materials are shipped from one facility to another. The shipper's data are reported to the IAEA in an ICR and are, in principle, verifiable. The degree to which such a verification is reliable depends on (1) whether the shipping facility is in another country, in which case collusion is rejected;

(2) whether a measurement verification of the shipment occurred at the shipper;

(3) whether the shipped material is sealed and unsealed by IAEA inspectors; and

(4) whether the receiving facility remeasures the received nuclear material so as to allow an $S / R$ comparison.

Analogous statements apply to the verifiable receiver's data for material shipped from a facility.

In addition, both the shipping and receiving State are required to provide the IAEA with advance notification concerning international transfers of nuclear materials to allow for verification at both the shipping and receiving facilities.

\section{IV.2.2 Flow Data}

The feed, product, waste, and scrap flows to and from a given facility are reported to the IAEA in ICRs and are all subject to IAEA verification. These flows would all be measured quantitatively by the operators at almost all BHFs. The frequency of inspections at many BHFs is in fact determined primarily by the need to verify these flows. For reactors and for reprocessing-plant spent-fuel pools, the flows are currently verified by item and perhaps attribute check, not by variables-measurement verification. Fresh fuel received at reactors--their "feed"--is verified at PIVs or interim inspections. Irradiated fuel leaving the reactor spent-fuel pools--their "product"--is verified only when shipments of partially filled casks are made.

A key distinction among several of the approaches is the number and type of flow verifications made. The primary importance of certain of these verifications and the supplementary nature of others was emphasized many years ago (Bennett et a1. 1971). 


\section{IV.2.3 Inventory Data}

When LWRs are refueled, and more often if necessary to maintain an annual schedule, and attendant upon cleanout PITs at BHFs, the IAEA verifies the entire physical inventory of all nuclear facilities and their annual material balance. If timeliness requirements so dictate, interim verifications of the inventory occur. Often inspections for interim inventory verifications would coincide with or be tantamount to visits for flow verifications. For reactors, spentfuel-pool surveillance cameras are serviced at interim inspections. Depending upon negotiated arrangements, their film or tape is either reviewed in the field or sent to Vienna for review.

Facility inventory information is reported to the IAEA by the State in Physical Inventory Lists (PILs). The annual material balance is reported in MBRs. 


\section{V.1 General Remarks}

Having defined three reference fuel cycles of markedly different complexity and the types of information available to the IAEA for verification, we can compare the collection of fuel-cycle approaches defined in Chapter III to one another qualitatively. Tables $V-1, V-2$, and $V-3$ show the results for the three State fuel cycles. (The footnotes and an explanation of the notation for all three follow Table $V-1$.$) The tables summarize the descriptions below,$

The columns of the tables represent the different safeguards approaches. The rows represent, first, the classes of verifiable safeguards information from safeguards inspections and, second, the relative effort and effectiveness of the approaches. The rows are grouped by facility type. Symbols in the row and column intersections give the status of the row item according to the safeguards approach of the particular column. (To facilitate understanding, we urge the reader to remove from the bound report the second set of Tables $V-1, V-2$, and $V-3$ with notes in Appendix $B$ and consult them while reading the text descriptions.)

The important point for fuel-cycle dependence is whether the safeguards verifications at a given facility type differ qualitatively from those under the facility-oriented approach as a function of fuel-cycle complexity. The tables show that they do. The tables also indicate the number of flow verifications required and qualitative changes in DP coverage and effort for the approaches with respect to the facility-oriented approach. These numbers and qualitative changes require detailed study based on real fuel cycles before they can form the basis for any plan of implementation.

Note that quantitative rules that govern the overall level of randomization in the first randomization-over-activities approach and the degree of relaxation in the goal-relaxation approach are not specified but are assumed to be fuel-cycle dependent. This assumption, however, does not affect the pattern of entries for these approaches in the tables.

\section{V.2 Comparison of the Approaches for Reactors Only}

For all facilities the facility-oriented approach requires that feed and product he verified and that the physical inventory be verified annually and, as timeliness dictates, on an interim basis as well. For reactors this means that any fresh-fuel assemblies received or spent-fuel assemblies shipped be verified and that their inventories be checked periodically. Fresh fuel is verified at inventory verifications. Only partially filled casks of spent fuel, reactor "product," are verified--by sealing. All are to be verified upon receipt elsewhere. In addition, fuel assemblies in the core and those transferred in or out are verified at refueling.

The information-correlation approach involves the same verifications as does the facility-oriented approach because there are no other facility types within the fuel cycle from which to draw correlative information. 
TABLE V-1. Comparison of the Approaches for a Fuel Cycle with Reactors Only

\begin{tabular}{|c|c|c|c|c|c|c|c|c|}
\hline $\begin{array}{c}\text { Information } \\
\text { Class }\end{array}$ & $\begin{array}{l}\text { Facility- } \\
\text { Oriented }\end{array}$ & $\begin{array}{l}\text { In forma- } \\
\text { tion } \\
\text { Correla- } \\
\text { tion }\end{array}$ & Zone & $\begin{array}{l}\text { Randon- } \\
\text { ization } \\
\text { over } \\
\text { Activi- } \\
\text { ties( I) }\end{array}$ & $\begin{array}{l}\text { Randon- } \\
\text { ization } \\
\text { over } \\
\text { Activi- } \\
\text { ties(II) }\end{array}$ & $\begin{array}{l}\text { Random- } \\
\text { ization } \\
\text { over } \\
\text { Facili- } \\
\text { ties }\end{array}$ & $\begin{array}{l}\text { Goal } \\
\text { Rel axa- } \\
\text { tion }\end{array}$ & $\begin{array}{l}\text { As sump- } \\
\text { tion } \\
\text { Change } 2,3\end{array}$ \\
\hline \multicolumn{9}{|l|}{ REACTORS (LEU) } \\
\hline Fresh Fuel Inventory 4,5 & $x$ & $x$ & $x$ & $<x$ & $Y$ & $\left\langle \#^{8}\right.$ & $<x$ & $x^{8}$ \\
\hline Core Refuelling 6 & $x$ & $x$ & $x$ & $<x$ & Y & $\#$ & $<x$ & $x$ \\
\hline Spent-Fuel Inventory ${ }^{4}$ & $x$ & $x$ & $x$ & $<x$ & $y$ & $\angle \#^{8}$ & $<x$ & $x^{8}$ \\
\hline Spent-Fuel Shipnents ${ }^{5,7}$ & $x$ & $x$ & $x$ & $<x$ & $y$ & $<\#$ & $<x$ & \\
\hline Change in DP Coverage & Basis & 0 & 0 & $0^{9}$ & 0 & $0^{9}$ & $0^{9}$ & - \\
\hline Change in Effort & Basis & 0 & 0 & - & 0 & - & - & - \\
\hline
\end{tabular}




\section{NOTES FOR TABLES $V-1, v-2$, and $v-3$}

Notation: $X$ represent the verification activities of the facility-oriented approach.

$Y$ represents different intensities of verification activities than $x$, but encompassing the same effort per facility.

$\Delta, \delta$ represent additional inspection activities.

$<X$ means fewer activities than $X$.

A blank box means that no activities are conducted.

\# means that activities are conducted at the number of facilities within the fuel cycle.

$<\#$ means that activities are conducted at fewer than the number of facilities within the fuel cycle.

,,+- 0 describe facility-specific changes in the number of diversion paths covered and in inspection effort with respect to the DP coverage and effort in the facility-oriented approach ("Basis").

$n / N$ gives the number of flow-verification inspections for a single shipment ( $n$ ) per facility pair (e.g., one conversion and one fabrication plant) and for a year's worth of shipments $(N)$ for all such pairs in the fuel cycle. For the latter, the following assumptions apply: 12 feed and product shipments occur annually at the conversion and LEU and MOX fabrication plants; 4 each occur at the LWRs; and 24 each occur at the reprocessing plant. The nature and intensity of these verifications vary over plant types and safeguards approaches.

1 Variants I and II of the randomication-over-activities approach respectively describe the cases of reduced and equal but differently distributed overall effort with respect to the effort required by the facility-oriented approach.

2 Not recommended sor future study by the Consultants (IAEA 1985).

3 For the specific change of diversion assumption discussed in Section III.3.6.

4 Reactor fresh-fuel receipts and spent-fuel inventories are verified both during PIVs and interim inventory verifications.

5 The verification of reactor fresh-fuel receipts and spent-fuel shipments in the fuel cycle with reactors only, of conversion-plant feed and of reactor spent-fuel shipments in the fuel cycles without reprocessing, and of conversion-plant feed in the closed fuel cycle could be el iminated within any approach by relying on international interdependence.

6 Includes verification during a PIV of fresh fuel going into the core, spent fuel coming out, and irradiated fuel remaining. If an annual refueling does not occur, the refueling verification is replaced by a check of the core containment seal where applicable. 


\section{NOTES (cont'd.)}

7 Sealing only of partially filled spent-fuel casks sent from reactors.

8 Verified at all reactors once a year during the PIV.

9 Lower probability of detection than in the facility-oriented approach for each DP covered.

10 Including neutron-collar verification of fresh-fuel assemblies. This could be done at the LEU and MOX fabrication plants within the zone approach if the assemblies are then sealed. Effectiveness suggests doing the verification as late as possible before insertion into the reactor core, and zone efficiency suggests eliminating flow verifications at the fabrication plants. of course, the collar verification could be done at the reactors within the facility approach.

11 The interim inventory period for MOX-fueled reactors is governed by the timeliness criterion for plutonium in unirradiated MOX assemblies in the freshfuel store. This requires more frequent verifications ( $\delta$ ) in all approaches.

12 Inspection-effort savings from the elimination of flow verifications at facilities processing plutonium must be evaluated in light of the need to conduct interim inventory inspections to satisfy timeliness goals. 
For the zone approach, reactors encompass parts of two zones--one for fresh fuel and one for irradiated fuel. During core-opening PIVs, the transfer from the fresh-fuel storage area to the core is verified as an interzone flow within the zone approach.

Variant I of the randomization-over-activities approach involves the same activities as the facility-oriented approach, but with a lower total effort. Thus the same DPS would be covered but at a. lower probability of detection for each. Variant II would involve different intensities of activities than the facility-oriented approach but with the same total effort. Thus similar DPS could be covered but with a different and more flexible emphasis.

The randomization-over-facilities approach also involves the same verified activities as the facility-oriented approach, but with omission of all activities at certain facilities ( $\angle \#$ in Table $V-1$ ). Thus the same DPs would be covered, but at a lower average detection probability. By assumption, annual PIVs are not subject to randomization over facilities (Section III.1).

The goal-relaxation approach involves the same verified classes of activities as the facility-oriented approach, but at generally lower levels of intensity, e.g., fewer sampled items for assay $(\langle X)$. This lowers the overall effort and decreases the probability of detection of DPS, the same number of which are covered as in the facility-oriented approach.

Since there are no BHFs in the fuel cycle, the change in the assumption about diversion possibilities, permitting only those based on demonstrated technological skills, induces a reduction in required verifications. The annual PIV is retained as the minimum verification (Section III.1).

\section{V.3 Comparison of the Approaches for Fresh-Fuel Facilities and Reactors}

According to the facility-oriented approach, all flows to and from all facilities are verified. Thus there are two verifications of the $\mathrm{UO}_{2}$ shipped from the single conversion plant to the fabrication plants in this second fuel cycle as well as two verifications of the assemblies shipped from the fabrication plants to the reactors. For all flows subject to double verification and especially for fuel assemblies, one verification could involve a measurement and the other a seal verification.

According to the information-correlation approach, flows between BHFs are only verified once. Thus, for the fuel cycle at hand, all fabrication-plant flows are verified, eliminating the need to verify the product from the conversion plant, but also resulting in fewer DPs covered. (Were the feed to the conversion plant not verified by virtue of verification of or reliance on shipper data--international interdependence--only infrequent verifications of minor flows would need to be done there.) The elimination of fresh-fuel verifications at reactors lacks great practical significance in terms of inspection effort because such verifications are not made at the time of receipt under the facility-oriented approach, but rather at an interim verification or core-opening PIV. Under the information-correlation approach therefore, the reactors and fabrication plants undergo the same inspections and therefore have the same DP coverage as under the facility-oriented approach. 
TABLE V-2. Comparison of the Approaches for a fuel Cycle with fresh-fuel facilities and Reactors

\begin{tabular}{|c|c|c|c|c|c|c|c|c|}
\hline Approach & $\mid \begin{array}{l}\text { Fac il ity- } \\
\text { Or iented }\end{array}$ & $\begin{array}{l}\text { In forma- } \\
\text { tion } \\
\text { Correla- } \\
\text { tion }\end{array}$ & Zone & $\begin{array}{l}\text { Randan- } \\
\text { ization } \\
\text { over } \\
\text { Activi- } \\
\text { ties(I) }\end{array}$ & $\begin{array}{l}\text { Random- } \\
\text { ization } \\
\text { over } \\
\text { Activi- } \\
\text { ties(II) }\end{array}$ & $\begin{array}{l}\text { Randon- } \\
\text { ization } \\
\text { over } \\
\text { Facili- } \\
\text { ties }\end{array}$ & $\begin{array}{l}\text { Goal } \\
\text { Relaxa- } \\
\text { tion } 2\end{array}$ & $\begin{array}{l}\text { As sump- } \\
\text { tion } \\
\text { Change } 2,3\end{array}$ \\
\hline \multicolumn{9}{|l|}{ CONVERSION PLANT } \\
\hline Conversion Feed ${ }^{5}$ & $x$ & $x$ & $x$ & $<x$ & Y & $x$ & $<x$ & \\
\hline Conversion Inventory & $x$ & $x$ & $x$ & $<x$ & $\mathbf{Y}$ & $x$ & $<x$ & $x$ \\
\hline Conversion Waste & $x$ & $x$ & $x$ & $<x$ & $\mathbf{Y}$ & $x$ & $<x$ & \\
\hline Conversion Product & $x$ & & & $<x$ & $Y$ & $x$ & $<x$ & \\
\hline Change in DP Coverage & Basis & - & - & $0^{9}$ & 0 & 0 & $0^{9}$ & - \\
\hline Change in Effort & Basis & - & - & - & 0 & 0 & - & - \\
\hline CONV-FAB F1ow Verifications & $2 / 36$ & $1 / 24$ & $0 / 0$ & $2 / 36$ & $2 / 36$ & $2 /<36$ & $2 / 36$ & $0 / 0$ \\
\hline \multicolumn{9}{|l|}{ LEU FABRICATION PLANTS } \\
\hline Fabrication Feed & $x$ & $x$ & & $<x$ & $Y$ & $<\#$ & $<x$ & \\
\hline Fabrication Inventory & $x$ & $x$ & $x$ & $<x$ & $\gamma$ & $\cdots$ & $<x$ & $x$ \\
\hline Fabrication Waste & $x$ & $x$ & $x$ & $<x$ & $Y$ & $<\#$ & $<x$ & \\
\hline Fabrication Product & $x$ & $x$ & 10 & $<x$ & Y & $<\#$ & $<x$ & \\
\hline Change in DP Coverage & Basis & 0 & - & $0^{9}$ & 0 & - & $0^{9}$ & - \\
\hline Change in Effort & Basis & 0 & - & - & 0 & $0^{9}$ & - & - \\
\hline FAB-REAC Flow Veriftcations & $2 / 52$ & $2 / 52$ & $1 / 28$ & $2 / 52$ & $2 / 52$ & $2 /<52$ & $2 / 52$ & $1 / 7$ \\
\hline
\end{tabular}


TABLE V-2 (cont'd.)

\begin{tabular}{|c|c|c|c|c|c|c|c|c|}
\hline $\begin{array}{l}\text { Information } \\
\text { Class }\end{array}$ & $\begin{array}{l}\text { Facility- } \\
\text { Oriented }\end{array}$ & $\begin{array}{l}\text { In forma- } \\
\text { tion } \\
\text { Correla- } \\
\text { tion }\end{array}$ & Zone & $\begin{array}{l}\text { Rand on- } \\
\text { ization } \\
\text { over } \\
\text { Activi- } \\
\text { ties(I) }\end{array}$ & $\left|\begin{array}{l}\text { Rand an- } \\
\text { ization } \\
\text { over } \\
\text { Activi- } \\
\text { ties( II) } 1\end{array}\right|$ & $\begin{array}{l}\text { Randon- } \\
\text { ization } \\
\text { over } \\
\text { Facili- } \\
\text { ties }\end{array}$ & $\begin{array}{l}\text { Goal } \\
\text { Relaxa- } \\
\text { tion }{ }^{2}\end{array}$ & $\begin{array}{l}\text { As sump- } \\
\text { tion } \\
\text { Change } 2,3\end{array}$ \\
\hline \multicolumn{9}{|l|}{ REACTORS (LEU) } \\
\hline Fresh Fuel Inventory ${ }^{4}$ & $x$ & $x$ & $x+\Delta^{10}$ & $<x$ & Y & $\angle \#^{8}$ & $<x$ & $x^{8}$ \\
\hline Core Refuell ing $^{6}$ & $x$ & $x$ & $x$ & $<x$ & Y & $\#$ & $<x$ & $x$ \\
\hline Spent-Fuel Inventory ${ }^{4}$ & $x$ & $x$ & $x$ & $<x$ & Y & $<^{8}$ & $<x$ & $x^{8}$ \\
\hline Spent-Fuei Shipments ${ }^{5,7}$ & $x$ & $x$ & $x$ & $<x$ & Y & $<\#$ & $<x$ & \\
\hline Change in DP Coverage & Basis & 0 & + & $0^{9}$ & 0 & $0^{9}$ & $0^{9}$ & - \\
\hline Change in Effort & Basis & 0 & + & - & $\mathbf{0}$ & - & - & - \\
\hline
\end{tabular}


For the zone approach, the entire fresh-fuel part of the fuel cycle constitutes one zone for material-accounting purposes; the cores and spent-fuel pools of the reactors constitute another (see Fig. II-1). Thus the feed entering the fresh-fuel zone is verified as the feed to the conversion plant, the product leaving the zone is verified as the fresh fuel entering the reactor cores, and no major flow need be verified at the fuel-fabrication plant. To compensate for the elimination of product fuel-assembly verification at fabrication plants by the neutron collar, fresh-fuel assemblies are verified by the collar at the reactors $(X+\Delta$ in Table $V-2$ for reactor fresh-fuel inventory). This imposes extra effort at reactors with respect to the qualitative (attributes or seals) verification in the facility-oriented approach and yields greater DP coverage. A major savings in effort results from the elimination of visits to the fabrication plant to verify the major flows. Alternately, the collar verification could occur at the fabrication plants, with the assemblies sealed there and verified at the reactors.

Variant I of the randomization-over-activities approach involves the same activities as the facility-oriented approach for all facilities, but with a lower total effort ( $<X$ in Table $V-2$ ). Thus the same DPs would be covered but at a lower probability of detection for each. Variant I I would involve different intensities of activities than in the facility-oriented approach but with the same total effort. Thus similar DPs could be covered, but with a different and more flexible emphasis.

The randomization-over-facilities approach also involves the same verified activities as the facility-oriented approach, but with omission of ali activities at certain facilities (<\# in Table $V-2$ ). Thus the same DPs would be covered but at a lower average probability of detection. Of course possibilities for randomization over seven reactors would be richer than over only two fabrication plants.

The goal-relaxation approach involves the same verified classes of activities as the facility-oriented approach, but at generally lower levels of intensity at each facility ( $<x$ in Table $V-2$ ), e.g., fewer sampled items for assay. This lowers the overall effort and decreases the probability of detection of DPs (footnote 9), the same number of which are covered as in the facility-oriented approach.

Finally, the assumption-change approach is radically different from the others. Since enrichment and reprocessing capability is absent, DPs involving fresh fuel are disregarded. Analogously, since reprocessing technology is absent, DPs involving spent fuel are disregarded. The annual PIV is retained by assumption. This lowers the overall effort as well as the number of DPs covered with respect to the facility-oriented approach.

\section{V.4 Comparison of the Approaches for a Closed Fuel Cycle}

According to the facility-oriented approach, all flows to and from all facilities are verified, implying double verification of all flows. In addition to the verifications for the LEU facilities just discussed for the fuel cycle without a back end, flow verifications are done under this approach for feed, product, and waste streams from the single reprocessing plant and from the three MOX fuel-fabrication plants. Because of the stringent timeliness criterion for 
TABLE V-3. Comparison of the Approaches for a Closed Fuel Cycle

\begin{tabular}{|c|c|c|c|c|c|c|c|c|}
\hline $\begin{array}{c}\text { Approach } \\
.\end{array}$ & $\left|\begin{array}{l}\text { Facility }- \\
\text { Or iented }\end{array}\right|$ & $\begin{array}{l}\text { Informa- } \\
\text { tion } \\
\text { Correla- } \\
\text { tion }\end{array}$ & Zone & $\begin{array}{l}\text { Randon- } \\
\text { ization } \\
\text { over } \\
\text { Activi- } \\
\text { ties(I) } 1\end{array}$ & $\left|\begin{array}{l}\text { Random- } \\
\text { ization } \\
\text { over } \\
\text { Activi- } \\
\text { ties(II) }\end{array}\right|$ & $\begin{array}{l}\text { Randon- } \\
\text { ization } \\
\text { over } \\
\text { Facili- } \\
\text { ties }\end{array}$ & $\begin{array}{l}\text { Goal } \\
\text { Relaxa- } \\
\text { tion }{ }^{2}\end{array}$ & $\begin{array}{l}\text { As sump- } \\
\text { t ion } \\
\text { Change } 2,3\end{array}$ \\
\hline \multicolumn{9}{|l|}{ CONVERSION PLANT } \\
\hline Conversion Feed ${ }^{5}$ & $x$ & $x$ & $x$ & $<x$ & r & $x$ & $<x$ & \\
\hline Conversion Inventory & $x$ & $x$ & $x$ & $<x$ & y & $x$ & $<x$ & \\
\hline Conversion Waste & $x$ & $x$ & $x$ & $<x$ & y. & $x$ & $<x$ & \\
\hline Conversion Product & $x$ & & & $<x$ & r & $x$ & $<x$ & \\
\hline Change in DP Coverage & Basis & - & - & $0^{9}$ & 0 & 0 & $0^{9}$ & Same \\
\hline Change in Effort & Basis & - & - & - & 0 & 0 & - & \\
\hline CONV-FAB Flow Verifications & $2 / 48$ & $1 / 36$ & $0 / 0$ & $2 / 48$ & $2 / 48$ & $2 /<48$ & $2 / 48$ & as \\
\hline \multicolumn{9}{|l|}{ LEU FABRICATION PLANTS } \\
\hline Fabrication Feed & $x$ & $x$ & & $<x$ & Y & $<\#$ & $<x$ & Facility- \\
\hline Fabrication Inventory & $x$ & $x$ & $x$ & $<x$ & Y & $\#$ & $<x$ & \\
\hline Fabrication Waste & $x$ & $x$ & $x$ & $<x$ & Y & $<\#$ & $<x$ & Oriented \\
\hline Fabrication Product & $x$ & $x$ & 10 & $<x$ & $Y$ & $<\#$ & $<x$ & \\
\hline Change in DP Coverage & Basis & 0 & - & $0^{9}$ & 0 & $0^{9}$ & $0^{9}$ & \\
\hline Change in Effort & Basis & 0 & - & - & 0 & - & - & \\
\hline FAB-REAC Flow Verifications & $2 / 120$ & $2 / 120$ & $1 / 84$ & $2 / 120$ & $2 / 120$ & $2 /<120$ & $2 / 120$ & \\
\hline
\end{tabular}


TABLE V-3 (cont'd.)

\begin{tabular}{|c|c|c|c|c|c|c|c|c|}
\hline $\begin{array}{l}\text { Approach } \\
\text { Inforination } \\
\text { Class }\end{array}$ & $\begin{array}{l}\text { Facility- } \\
\text { Oriented }\end{array}$ & $\begin{array}{l}\text { In forma- } \\
\text { t i on } \\
\text { Correl a- } \\
\text { t i on }\end{array}$ & Zone & $\begin{array}{l}\text { Random- } \\
\text { ization } \\
\text { over } \\
\text { Activi- } \\
\text { ties }(1)^{1}\end{array}$ & $\begin{array}{l}\text { Random } \\
\text { ization } \\
\text { over } \\
\text { Activi- } \\
\text { ties(II) }\end{array}$ & $\begin{array}{l}\text { Random- } \\
\text { ization } \\
\text { over } \\
\text { Facili- } \\
\text { ties }\end{array}$ & $\begin{array}{l}\text { Goal } \\
\text { Relaxa- } \\
\text { tion }\end{array}$ & $\begin{array}{l}\text { As sump- } \\
\mathrm{t} \text { i on } \\
\text { Change } 2,3\end{array}$ \\
\hline \multicolumn{9}{|l|}{ REACTORS (LEIJ and MOX) } \\
\hline Fresh-Fuel Inventory ${ }^{4}, 11$ & $x+\delta$ & $x+\delta$ & $x+\delta+\Delta^{10}$ & $<x+\delta$ & $\gamma+\delta$ & $\angle \#^{8}$ & $<x+\delta$ & Same \\
\hline Core Refuel ing ${ }^{6}$ & $x$ & $x$ & $x$ & $<x$ & Y & $\#$ & $<x$ & \\
\hline Spent-Fuel Inventory ${ }^{4}$ & $x$ & $x$ & $x$ & $<x$ & $\gamma$ & $\angle \#^{8}$ & $<x$ & as \\
\hline Spent-Fuel Shipments ${ }^{7}$ & $x$ & & & $<x$ & $\gamma$ & $<\#$ & $<x$ & \\
\hline Change in DP Coverage & Basis & 0 & - & $0^{9}$ & 0 & $0^{9}$ & $0^{9}$ & Facility \\
\hline Change in Ef fort & Basis & 0 & + & - & 0 & - & - & \\
\hline REAC-RPR Flow Verifications & $2 / 108$ & $1 / 84$ & $0 / 0$ & $2 / 108$ & $2 / 108$ & $2 /<108$ & $2 / 108$ & Oriented \\
\hline
\end{tabular}


TABLE V-3 (cont'd.)

\begin{tabular}{|c|c|c|c|c|c|c|c|c|}
\hline Approach & $\mid \begin{array}{l}\text { Facil ity- } \\
\text { Or iented }\end{array}$ & $\begin{array}{l}\text { Informa- } \\
\text { tion } \\
\text { Correl a- } \\
\text { tion }\end{array}$ & Zone & $\begin{array}{l}\text { Random- } \\
\text { ization } \\
\text { over } \\
\text { Activi- } \\
\text { ties( I) }\end{array}$ & $\left|\begin{array}{l}\text { Random- } \\
\text { ization } \\
\text { over } \\
\text { Activi- } \\
\text { ties(II) }\end{array}\right|$ & $\begin{array}{l}\text { Rand om- } \\
\text { ization } \\
\text { over } \\
\text { Facili- } \\
\text { ties }\end{array}$ & $\begin{array}{l}\text { Goal } \\
\text { Relaxa- } \\
\text { tion }{ }^{2}\end{array}$ & $\begin{array}{l}\text { As sump- } \\
\text { tion } \\
\text { Change } 2,3\end{array}$ \\
\hline \multicolumn{9}{|l|}{ REPROCESSING PLANT } \\
\hline Spent-Fuel Receipts & $x$ & $x$ & 12 & $<x$ & Y & $x$ & $<x$ & Same \\
\hline Spent-Fuel Inventory & $x$ & $x$ & $x$ & $<x$ & $Y$ & $x$ & $<x$ & \\
\hline Spent-Fuel Dissolution & $x$ & $x$ & $x$ & $<x$ & r & $x$ & $<x$ & \\
\hline Product, Process Inventory & $x$ & $x$ & $x$ & $<x$ & Y & $x$ & $<x$ & as \\
\hline Waste & $x$ & $x$ & $x$ & $<x$ & $Y$ & $x$ & $<x$ & \\
\hline Product (Pu \& U) Shipnents & $x$ & $x$ & 12 & $<x$ & $Y$ & $x$ & $<x$ & Facility \\
\hline Change in DP Coverage & Basis & 0 & - & $0^{9}$ & 0 & 0 & $0^{9}$ & \\
\hline Change in Effort & Básis & 0 & - & - & 0 & 0 & - & Oriented \\
\hline RPR-MFAB Flow Verifications & $2 / 60$ & $1 / 24$ & $0 / 0$ & $2 / 60$ & $2 / 60$ & $2 /<60$ & $2 / 60$ & \\
\hline
\end{tabular}


TABLE $v-3$ (cont'd.)

\begin{tabular}{|c|c|c|c|c|c|c|c|c|}
\hline Approach & $\mid \begin{array}{l}\text { Facility- } \\
\text { Oriented }\end{array}$ & $\begin{array}{l}\text { In forina- } \\
\text { t ion } \\
\text { Correl a- } \\
\text { tion }\end{array}$ & Zone & $\begin{array}{l}\text { Random- } \\
\text { i zation } \\
\text { over } \\
\text { Activi- } \\
\text { ties(I)1 }\end{array}$ & $\begin{array}{l}\text { Random- } \\
\text { ization } \\
\text { over } \\
\text { Activi- } \\
\text { ties(II) }\end{array}$ & $\begin{array}{l}\text { Random- } \\
\text { i zation } \\
\text { over } \\
\text { Facili- } \\
\text { ties }\end{array}$ & $\begin{array}{l}\text { Goal } \\
\text { Re laxa- } \\
\text { tion }\end{array}$ & $\begin{array}{l}\text { As sump- } \\
\text { ti on } \\
\text { Change } 2,3\end{array}$ \\
\hline \multicolumn{9}{|l|}{ MOX FABRICATION PLANTS } \\
\hline MOX Feed & $x$ & 12 & 12 & $<x$ & Y & $<\#$ & $<x$ & \\
\hline MOX Inventory (PIV) & $x$ & $x$ & $x$ & $<x$ & Y & $\#$ & $<x$ & Same \\
\hline MOX Inventory (Interim) & $x$ & $x$ & $x$ & $<x$ & Y & $<\#$ & $<x$ & \\
\hline MOX Waste & $x$ & $x$ & $x$ & $<x$ & $\mathbf{Y}$ & $<\#$ & $<x$ & as \\
\hline MOX Product & $x$ & $x$ & 10,12 & $<x$ & $Y$ & $<\#$ & $<x$ & \\
\hline Change in DP Coverage & Basis & - & - & $0^{9}$ & 0 & $0^{9}$ & $0^{9}$ & Facility \\
\hline Change in Ef fort & Basis & - & - & - & 0 & - & - & \\
\hline MOX-REAC Flow Verifications & $2 / 120$ & $2 / 120$ & $1 / 84$ & $2 / 120$ & $2 / 120$ & $2 /<120$ & $2 / 120$ & Oriented \\
\hline
\end{tabular}


plutonium, frequent interim inventory inspections are performed at these four facilities. For the same reason, when Mox fuel assemblies are stored prior to empl acement within the reactor cores, MOX-fueled reactors require more frequent interim inventory verifications than do LEU-fueled reactors. For MoX-fueled reactors, increases or decreases due to randomization, goal changes or the collar measurement within the zone approach refer to this base of extra activity $(x+\delta$ in Table $V-3)$.

According to the information-correlation approach, flows between BHFs within the fuel cycle are verified once only. In addition to the verifications under this approach discussed for the LEU facilities for the fuel cycle without a back end, all reprocessing-plant flows are verjfied under this approach. Verification of the feed to the MOX plants is based on reprocessing-plant product verification, while product MOX assemblies are verified at the MOX plants.

For the zone approach, the LEU fresh-fuel verifications are the same as for the fuel cycle without a back end, which yields an increase in DP coverage at the reactors. However, since irradiated-fuel shipments, as intrazone transfers, are not checked as flows but only at PIVs or interim inventory verifications, some DP coverage is lost at the reactors. (Overall, no net change in DP coverage is ascribed to the reactors according to the zone approach). The process area of the reprocessing plant and the entirety of the MOX fuel-fabrication plants constitute the plutonium zone of the fuel cycle (see Figure II-1). (The reprocessing-plant spent-fuel pool is part of the irradiated-fuel zone.) They undergo PIVs on a zone basis. While the transfers between zones at the head end of the reprocessing plant are verified, the intrazone transfers between the reprocessing plant and the MOX plants are not. The MOX-plant product assemblies are verified at the reactors, in analogy with the situation for LEU assemblies in the LEU zone described in the previous section. The fresh-fuel storage areas of these MOX-fueled reactors in effect are part of the plutonium zone. Al ternately, MOX assembly verification could be done and the assemblies sealed at the MOX plant. Required interim inventory verifications at the reprocessing and MOX plants decrease the effort savings otherwise gained by el iminating major-flow verjfications there.

Variant I of the randomization-over-activities approach involves the same activities as the facjlity-orjented approach, but with a lower total effort $(\langle x)$. Thus the same DPS could be covered but at a lower probability of detection for each. Varjant II involves different intensities of activities than the facility-oriented approach but the same total effort. Thus similar ops could be covered, but with a different and more flexible emphasis.

The randomization-over-facilities approach al so involves the same verified activities as the facility-oriented approach, but with the omission of all activities at certain facilities (<\#). Thus the same DPs would be covered but at a lower average probability of detection. Of course possibilities for randomization over 21 reactors would be richer than over three LEU and three MOX fuel-fabrication plants.

The goal-relaxation approach involves the same verified classes of activities as the facility-orjented approach, but at generally lower levels of intensity at each facility $(\langle X)$, e.g., fewer sampled items for assay. This lowers the overall effort and decreases the probability of detection of DPs (footnote $9)$, the same number of which are covered as in the facility-oriented approach. 
The existence of a reprocessing plant means that spent fuel can be diverited and the diversion credibly concealed. Hence, by default, the assumption-change approach is the same as the facility-oriented approach for all facilities within this fuel cycle. 


\section{DISCUSSION}

\section{VI.I Intrinsic and Extrinsic Fuel-Cycle Dependence}

The tabular analysis of Chapter $V$ shows that the collection of routinely verifiable nuclear-material information classes is a reasonable framework for the comparison of IAEA safeguards approaches. For States subject to full-scope safeguards, this framework distinguishes the facility-oriented approach from fuel-cycle-oriented approaches. By definition, an approach is fuel-cycleoriented if safeguards applied at a given facility type differ from those applied under the facility-oriented approach because of fuel-cycle complexity.

Among fuel-cycle-oriented approaches, a useful distinction that becomes apparent from Tables $V-1, V-2$, and $V-3$ is that of intrinsic versus extrinsic fueh-cycle dependence. We define a safeguards approach to be intrinsically fuel-cycle-dependent if the representation in the tables for some facility type is qualitatively different (e.g., by including blank entries) from its representation under the facility-oriented approach. We define a safeguards approach to be extrinsically fuel-cycle-dependent if the table representations for all facility types differ only from their representation under the facility-oriented approach in a quantitative way. More simply stated, intrinsically fuel-cycle-dependent approaches lack entire classes of verifications that occur under the facility-oriented approach because their very definition suggests fuel-cycle depenence.

Table VI-1 lists all the safeguards approaches examined in Chapter $V$ according to these definitions.

Quantitative changes that characterize extrinsically fuel-cycle-dependent approaches could either be uniform across facilities within a given fuel cycle, in which case there is no fuel-cycle dependence on the overall fuel cycle, (e.g., a change in the probability of detection by NDA of defects in all attributes measurements), or be nonuniform, in which case there is dependence on the facilities within the fuel cycle (e.g., a change in the probability of detection by NDA of defects in spent-fuel assemblies dependent on the fraction of electric power in the state generated by nuclear reactors). In the former case, percentage reductions in effort would not depend on the size or complexity of the fuel cycle.

While quantitative analysis is needed to substantiate this conclusion, it is evident that both intrinsically and extrinsically fuel-cycle-dependent approaches reduce safeguards inspection effort for complex fuel cycles as compared to the facility-oriented approach by el iminating verifications. Their effect on safeguards inspection effectiveness depends crucially on the goals set for the approaches.

An additional conclusion suggested by Table VI-1 and strengthened by consideration of their specifics is that the goal-relaxation and randomizationover-activities (Variant I) approaches are similar regarding effort, overall probability of detection, and verifications accomplished if the quantitative rules that govern their extrinsic fuel-cycle dependence are the same.

\section{VI.2 Effort and Effectiveness Considerations}

VI.2.1. Effort

In addition to displaying the classification of the safeguards approaches according to the verifications they encompass, Tables $v-1, v-2$, and $V-3$ present 
Table VI-1

Classification of the Safeguards Approaches

A. Intrinsic Fuel-Cycle Dependence

1. Zone

2. Randomization Over Facilities

3. Information-Correlation

4. As sumption Change

B. Extrinsic Fuel-Cycle Dependence

1. Randomization Over Activities (Variants I and II)

2. Goal Relaxation

C. No Fuel-Cycle Dependence ${ }^{a}$

1. Facility-Oriented

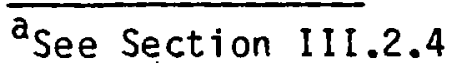

qualitatively their effort requirements with respect to the effort requirements of the facility-oriented approach. The effort required to conduct the verifications is summarized in the tables at the facility level. It would require an effort-allocation scheme to compare the approaches on the bas is of equal effort.

The potential savings in inspection effort due to the decrease in the number of verifications of flows according to some approaches must be evaluated in light of the number of interim inventory verifications conducted. Thus, savings are potentially large in the Zone 1 facilities (Tables $V-2$ and $V-3$ ), because by assumption for the facility-oriented approach, there are monthly verifications of the shipments of $\mathrm{UO}_{2}, \mathrm{UF}_{6}$, and LEU fuel assemblies but no interim inventory verifications to satisfy timeliness goals. Savings are potentially smali in Zone 3 because there are monthly interim inventory inspections which encompass monthly verifications of the flows of $\mathrm{PuO}_{2}$ and $\mathrm{MOX}$ assemblies at the MOX fabrication plant and monthly interin inventory verifications and biweekly verifications of the flows of $\mathrm{PuO}_{2}$ at the reprocessing plant. Given continuous inspection, the savings would probably be nil.

\section{VI.2.2. Paragraph 81 Factors}

With respect to the inspection parameters 1 isted in Paragraph 81 of INFCIRC/153, "...the actual number, intensity, duration, timing, and mode of routine inspections...", the different safeguards approaches compare variously to the facility-oriented approach. The parameter changes are ininerent in Tables $V-1, V-2$, and $V-3$ and are most pronounced for the closed fuel cycle, on which this section focuses, for all approaches except the assumption-change approach.

First, Variant II of the randomization-over-activities is the sole other approach identical to the facility-oriented approach with respect to the Paragraph 81 parameters. 
The information-correlation approach requires both less intense inspections at BHFs, since some flow verifications are dropped, as well as fewer inspections at LWRs, since spent-fuel shipments need not be verified. The zone approach involves many fewer and consequently less frequent inspections at BHFs since many flow verifications are eliminated.

Variant I of the randomization-over-activities approach and the goalrelaxation approach involve less intense inspections. The randomization-overfacilities approach requires fewer and therefore less frequent inspections at certain facilities.

Finally, in no facility in the closed fuel cycle under any apprnach is there a likely change in the mode of inspection (see Attachment $D$ of IAEA 1985) from continuous to intermittent.

\section{VI.2.3. Effectiveness}

Effectiveness, a more elusive concept, is summarized in Tables $V-1, V-2$, and $V-3$ by two measures, the change in the number of diversion paths covered at each facility type and the number of interfacility flow verifications carried out. The latter of course conveys effort information as well. Other quantitative measures of the effectiveness of the safeguards approaches at the facility or zone level include the accountancy verification goal (AVG; IAEA 1980) and the ratio of the annual inspection effort required to implement the approach to the amount of nuclear material (possibly weighted) thereby safeguarded (de Montmollin, Higinbotham, and Gupta 1985).

Quantitative measures do not, however, capture all aspects of the effectiveness question. In the zone approach, $M A$ is only verified completely at the zone level. The AVG for a zone with many facilities would generally be greater than that for a single facility. Meanwhile, the AVG for a single facility within the zone would generally be less if operator flow measurements were accepted without verification (so operator-inspector differences would not contribute to the measurement uncertainty), than if IAEA verifications of the facility flows occurred. But, facility conclusions would be drawn without complete IAEA verification of flows under a zone approach. Even more starkly, since flows are not verified at all within the assumption-change approach for the fuel cycle without a back end, MA at any level is at best partial. In such situations, effectiveness comparisons of approaches must be largely subjective since the standards are so different.

The unpredictability of the approaches based on randomization may have subjective safeguards value beyond that conveyed by the quantitative measures in the tables (Petit 1984).

Finally, the facility-oriented approach and the zone approach bound the possibilities for MA verification of the closed fuel cycle given the boundary condition that measurements of uranium and plutonium must be made before and after irradiation in reactors. The zone approach provides for the minimum number of verifications, the facility-oriented approach provides for the maximum number, and the information-correlation approach as illustrated here provides for an intermediate number. Any other approach that encompasses verified MA must lie within this range (cf. Bennett et al. 1971). 
Classification of safeguards approaches according to the information framework for different fuel cycles yields a qualitative comparison of their effectiveness and effort requirements by showing what verifications are to be done at each facility type. This qualitative comparison is no substitute for detailed analyses of these aspects based on the times required for specific inspection activities and their possible results. It would similarly be worthwhile to determine if there are significant differences between the facilityoriented and information-correlation approaches on the one hand and current IAEA practice on the other.

Another consideration not discussed at length here is the diversion and concealment scenarios each approach can reasonably counter (see Section III.3.2 and Appendix $E$ of Fishbone and Higinbotham 1986).

Practical considerations, especially constraints on inspector and equipment availability and the requirements for genuine randomization, were briefly alluded to in this analysis. They play an important role in actual safeguards implementation and they may affect different approaches differently.

No research facilities were assumed to exist in the reference fuel cycles. Their existence would affect the approach based on assumption changes and could affect others.

Finally, since there is no enrichment plant in any of the fuel cycles analyzed, the results apply as well to natural-uranium OLR fuel cycles.

VI.4 Further Work

Three lines of inquiry follow from the development herein.

First, since the framework for the comparison of safeguards approaches is entirely qualitative, it would be relatively simple to carry it out for any actual State fuel cycle or, indeed, all of them. The result would be the types of verification to be carried out at each facility according to each approach. If there were simple rules of thumb for determining the effort required to carry out the verifications, the fuel-cycle total could be determined.

A possible rule of thumb for comparing the effectiveness of the approaches is the relative number of a specified list of diversion paths covered by each. By considering such rules of thumb for the approaches as applied to actial fuel cycles, one could draw useful conclusions based on the framework anaTysis illustrated in Tables $V-1, V-2$, and $V-3$ for model fuel cycles.

Second, one could study any given approach or combination thereof in greater detail to ascertain quantitatively its relative effort requirement and effectiveness with respect to the facility-oriented approach (see, e.g., IAEA 1984a and Fishbone and Higinbotham 1986). Practical considerations affecting implementation of the approach should be identified. This would be the basic program to elucidate the approach of DP analysis for the fuel cycle as a whole (see Section III.3.4). 
One combination of particular interest is the zone approach for the freshfuel zone of a closed fuel cycle and the facility-oriented approach for the facilities within the plutonium zone (de Montmollin, Higinbotham, and Gupta 1985).

Third, field tests of promising approaches could be instituted by the IAEA as has been done already for the Canadian fuel cycle using the zone approach (Healey 1984). 


\section{REFERENCES}

Bahm, W., Shea, T., and Tolchenkov, D. 1980, "Some Safeguards Considerations for a Reference Mixed Oxide Fuel Element Fabrication Plant With an Annual Throughput of $500 \mathrm{Kg} \mathrm{PuO}_{2}$," IAEA/STR-89, Draft, International Atomic Energy Agency, Vienna, Austria.

Barton, J. H. and weiler, L. D. (editors) 1976, International Arms Control, Stanford University Press, Stanford, California. The text of the Treaty on the Non-Proliferation of Nuclear Weapons (NPT) is on p.414.

Beetle, T. 1985, "A Comprehensive Safeguards Test Statistic Without Flow Verification," IAEASSTR-187, International Atomic Energy Agency, Vienna, Austria.

Bennett, C. 1983, "Randomized Inspection-Light Water Reactors," unpublished.

Bennett, C., Granquist, D.P., Schneider, R.A., and Stewart, K.B., 1971, "The Conceptual Role of Redundancy in Verification," BNWL-SA-4062, Pacific Northwest Laboratories, Richland, Washington.

Brown, F. and Gupta, D. 1984, "International Safeguards - Problems and Prospects", Proceeding of the Sixth Annual Symposium on Safeguards and Nuclear Materials Management, ESARDA 17, p.65, European Safeguards Research and Development Association, Ispra, Italy.

de Montmollin, J. 1985, private communication.

de Montmollin, J., Higinbotham, W. A., Gupta, D. 1985, "Concept for Fuel- CycleBased Safeguard s", Nuclear Materials Management, Vol. XIV, No. 3 (Proceedings Issue), p. 554 .

Fishbone, L.G. and Higinbotham, W. A. 1986, "A Study of a Zone Approach to IAEA Safeguards: the Low-Enriched-Uranium Zone of a Light-Water-Reactor Fuel Cycle", BNL-38584/ISP0-196/TS0-86-15, Brookhaven National Laboratory, Upton, N.Y.

Glancy, J. E., McDaniel, T., and Swartz, J. 1980, "Diversion Path Analysis of Fuel Cycle with Multiple Light Water Reactor Facilities - Task 2", SAI01580592LJ, SAI, LaJolla, California.

Filancy, J., McDaniel, T., and Swartz, J. 1981, "Diversion Path Analys is of Fuel with Multiple Facilities", Final Draft Report, ISP0-129/SAI-01581-153L-J, SAI, LaJolla, Cal ifornia.

Goodwin, K. E., Schleter, J. C., and Maltese, M. D. K. 1978, Diversion Path Analys is Handbook, Vol umes 1-4, HCP/D6010-01/1-4, National Bureau of Standards, Washington, D.C.

Gordon, D. M. and Sanborn, J. B. 1984, "An Approach to IAEA Material-Balance Verification with Intermittent Inspection at the Portsmouth Gas Centrifuge Enrichment Plant," BNL-51782, Brookhaven National Laboratory, Upton, N.Y.

Grumm, H. 1984, "Safeguarding the Nuclear Fuel Cycle: Methodologies", IAEA Bulletin, vol.26, No.3 (September), p.20. 
Gupta, D., Avenhaus, R., Drosselmeyer, E., Hagen, A., Kraemer, R., and Nentwich; D. 1972, "Optimized Material Accounting for Safeguards in a Nuclear Fuel Cycle," Peaceful Uses of Atomic Energy, IAEA/STI/PUB/300/Vol. 9, p. 469, International Atomic Energy Agency, Vienna, Austria (co-published by the United Nations, New York).

Healey, G.J. 1984, "An Alternative Approach to Safeguards for the Canadian Natural Uranium Fuel Cycle--Concepts and Experience," unpublished.

Higinbotham, W. A. and Fishbone, L. G. 1985, "Case Study: Application of the Safeguards Assessment Methodology to a Medium-Sized Reprocessing Plant", ISP0-94, Brookhaven National Laboratory, Upton, New York 11973.

Houck, F. 1985, private communication.

IAEA 1972, "The Structure and Content of Agreements Between the Agency and States Required in Connection with the Treaty on the Non-Proliferation of $\mathrm{Nu}-$ clear Weapons", IAEA/INFCIRC/153 (Corrected), International Atomic Energy Agency, Vienna, Austria.

IAEA 1980, IAEA Safeguards Glossary, IAEA/SG/INF/1, International Atomic Energy Agency, Vienna, Austria.

IAEA 1984a, "Application of Safeguards to Multiple Facility Fuel Cycles", IAEA/ STR-171, International Atomic Energy Agency, Vienna, Austria; working paper for the December, 1984 Consultants' Meeting on the Application of Safeguards to Multiple Facility Fuel Cycles.

IAEA 1984b, "Safeguarding Low Enriched Uranium Conversion and Fuel Fabrication Facilities," IAEA/STR-157, International Atomic Energy Agency, Vienna, Austria.

IAEA 1985, "Report of the Consultant's Meeting on the Application of Safeguards to Multiple Facility Fuel Cycles - 10-14 December 1984", IAEA/STR-185, International Atomic Energy Agency, Vienna, Austria.

Imai, R. 1972, "Nuclear Safeguards", Adelphi Paper 86, The International Institute for Strategic Studies, London, U.K.

Kaniewski, J. 1983, "Routine Inspection Activities List (RIAL): (Model for a Reference LWR Facility)", IAEA/STR-138, International Atomic Energy Agency, Vienna, Austria.

Keisch, B. and Sanborn, J. B. 1984, "Case Study Application of the Safeguards Effectiveness Assessment Methodology to a Mixed Oxide Fuel Fabrication Facility", ISP0-212, Brookhaven National Laboratory, Upton, New York 11973.

Lovett, J., Ikawa, K., and Tsutsumi, M. 1983, "An Advanced Safeguards Approach for a Model $200 \mathrm{t} / \mathrm{a}$ Reprocessing Facility. Part I: Description and Discussion," IAEA/STR-140, Draft 5, International Atomic Energy Agency, Vienna, Austria.

Markin, J. T., Gutinacher, R. G., and Shipley, J. P. 1983, "The Interface Between Materials Accounting and Containment/Surveillance," LA-9976-MS, Los Alamos National Laboratory, Los Al amos, New Mexico. 
Menlove, H. 1982, "Passive/Active Coincidence Counter for Total Plutonium Measurement in MOX Fuel Assemblies," LA-9288-MS (ISP0-170), Los Ạlamos National Laboratory, Los Alamos, New Mexico.

Menlove, H. 0. and Keddar, A. 1982, "Field Test and Evaluation of the IAEA Coincidence Collar for the Measurement of Unirradiated BWR Fuel Assemblies," LA-9375-MS (ISP0-174), Los Alamos National Laboratory, Los Alamos, New Mexico.

Menlove, H. 0., Keddar, A., and Beets, C. 1981, "Field Test and Evaluation of the Coincidence Collar for the Measurement of Fresh PWR Fuel Assemblies," ISPO175 (LA-UR-82-2260), Los Alamos National Laboratory, Los Alamos, New Mexico.

Nakicenkovic, S. 1976, "Experience in the Application of Agency Inspection Practices", Safeguarding Nuclear Materials, IAEA/ST I/PUB/408, Vol. I, 379, International Atomic Energy Agency, Vienna, Austria.

OTA 1977, Nuclear Proliferation and Safeguards, OTA-E-50 Appendix IX, Volume II, Part One, Office of Technology Assessment, Congress of the United States, Washington, D.C.

Petit, A. 1984, "De La Necessite d'Approfondir le Consensus International Quant aux Implications Pratiques des Concepts de Base des Garanties Internationales", Proceedings of the Sixth ESARDA Symposium on Safeguards and Nuclear Material Management, ESARDA 17, p.41, European Safeguards and Development Association, Ispra, Italy.

Rosentha1, M. D. 1984, "Analysis of the Allocation and Distrijution of IAEA Inspection Effort in 1982", Proceedings of the Sixth Annual Symposium on Safeguards and Nuclear Material Management, ESARDA 17, p.51, European Safeguards Research and Development Association, Ispra, Italy.

Sanborn, J. 1981, "Case Study Application of the Safeguards Assessment Methodology to a Pressurized Water Reactor", ISPO-149, Brookhaven National Laboratory, Upton, New York.

Sanborn, J. B. 1984a, "Safeguards for Special Circumstances at Light Water Reactors", Draft, Brookhaven National Laboratory, Upton, New York.

Sanborn, J. B. 1984b, "Application of the Safeguards Assessment Methodology to a Boiling Water Reactor", ISP0-211, Brookhaven National Laboratory, Upton, New York.

Schneider, R. A., Ni lson, R., Herz, E. R., Ferraris, M., Gonzalex-Montes, H. and Thies, W. 1983, "Implementation of IAEA Safeguards at a U.S. Fuel Fabrication Plant", Proceedings of the Fifth Annual Symposium on Safeguards and Nuclear Material Management, ESARDA 16, p.437, European Safeguards Research and Development Association, Ispra, Italy. 
Stoll, W. 1983, "Operator's Experience with Safeguarding the Nuclear Fuel Cycle", Proceedings of the Fifth Annual Symposium on Safeguards and Nuclear Materials Management, ESARDA 16, p.321, European Safeguards Research and Development Association, Ispra, Italy.

Sukhoruchkin, V. 1979, "Safeguarding of Reprocessing Facilities," IAEA/STR-77, Draft of Preliminary Approach, International Atomic Energy Agency, Vienna, Austria.

Swartz, J., Glancy, J., and McDaniel, T. 1980, "Diversion Analysis of a Low Enriched Uranium Fuel Fabrication Facility," ISP0-124/SAI 01580-293LJ, SAI, La Jolla, California.

Thorstensen, S. E. and Thorne, L. 1981, "IAEA Safeguards Operations at a Bulk Facility", Proceedings of the Advanced International Training Course on State Systems of Accounting for a Control of Nuclear Materials, LA-8901-C, text from Los AT amos National Laboratory, Los ATamos, N.M.; course sponsored by U.S. Dept. of Energy in cooperation with the IAEA and presented by Los Alamos, Batelle Pacific Northwest Laboratories and Exxon Nuclear Company, Inc.

Ulvila, J. W. 1984, "Resource Allocation and Random Selection of Inspection Activities for a Generic Mixed 0xide Fuel Fabrication Facility", ISP0-206, Decision Science Consortium, Inc., Falls Church, Virginia.

Ulvila, J. W. and Brown, R. V. 1982, "Uses of SEAM Data for Resource Allocation and Random Selection of Inspection Activities: Methods and Illustrations", ISP0-188, Decision Science Consortium, Inc., Falls Church, Virginia.

Van den Bemden, E. 1980, Statement in "Panel Discussion on Experience on International Safeguards in Facilities", Proceedings of the 2nd Annual Symposium on Safeguards and Nuclear Material Management, ESARDA 11, 214, European Sa feguards Research and Development Association, Ispra, Italy.

Weinstock, E. V., 1982, "Effect of Existence of Reprocessing Plant on LWR Safeguards", unpublished. 


\section{APPENDIX A: GLOSSARY}

\begin{tabular}{|c|c|c|}
\hline AVG & - & Accountancy Verification Goal \\
\hline BHF & - & Bulk-Handling Facility \\
\hline BWR & - & Boiling-Water Reactor \\
\hline CONV & - & Conversion Plant \\
\hline $\mathrm{C} / \mathrm{S}$ & - & Containment and Surveillance \\
\hline DP & - & Diversion Path \\
\hline$F A B$ & - & (LEU) Fabrication Plant \\
\hline $\mathrm{FF}$ & - & Fresh Fuel \\
\hline I AEA & - & International Atomic Energy Agency \\
\hline ICR & - & Inventory Change Report \\
\hline I NFC IRC & - & Information Circular \\
\hline KMP & - & Key Measurement Point \\
\hline LEU & - & Low-Enriched Uranium \\
\hline LWR & - & Light-Water Reactor \\
\hline MA & - & Materials Accounting \\
\hline MBA & - & Material Balance Area \\
\hline MBR & - & Material Balance Report \\
\hline MFAB & - & Mox Fabrication Plant \\
\hline MIAL & - & Model Inspection Activities List \\
\hline MOX & - & Mixed Oxide (Uranium and Plutonium) \\
\hline MT & & Metric Ton \\
\hline MUF & - & Material Unaccounted For \\
\hline MWe & - & Megawatt electric \\
\hline NDA & 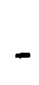 & Nondestructive Assay \\
\hline NPT & - & Non-Proliferation Treaty \\
\hline OLR & - & On-Load Reactor \\
\hline
\end{tabular}




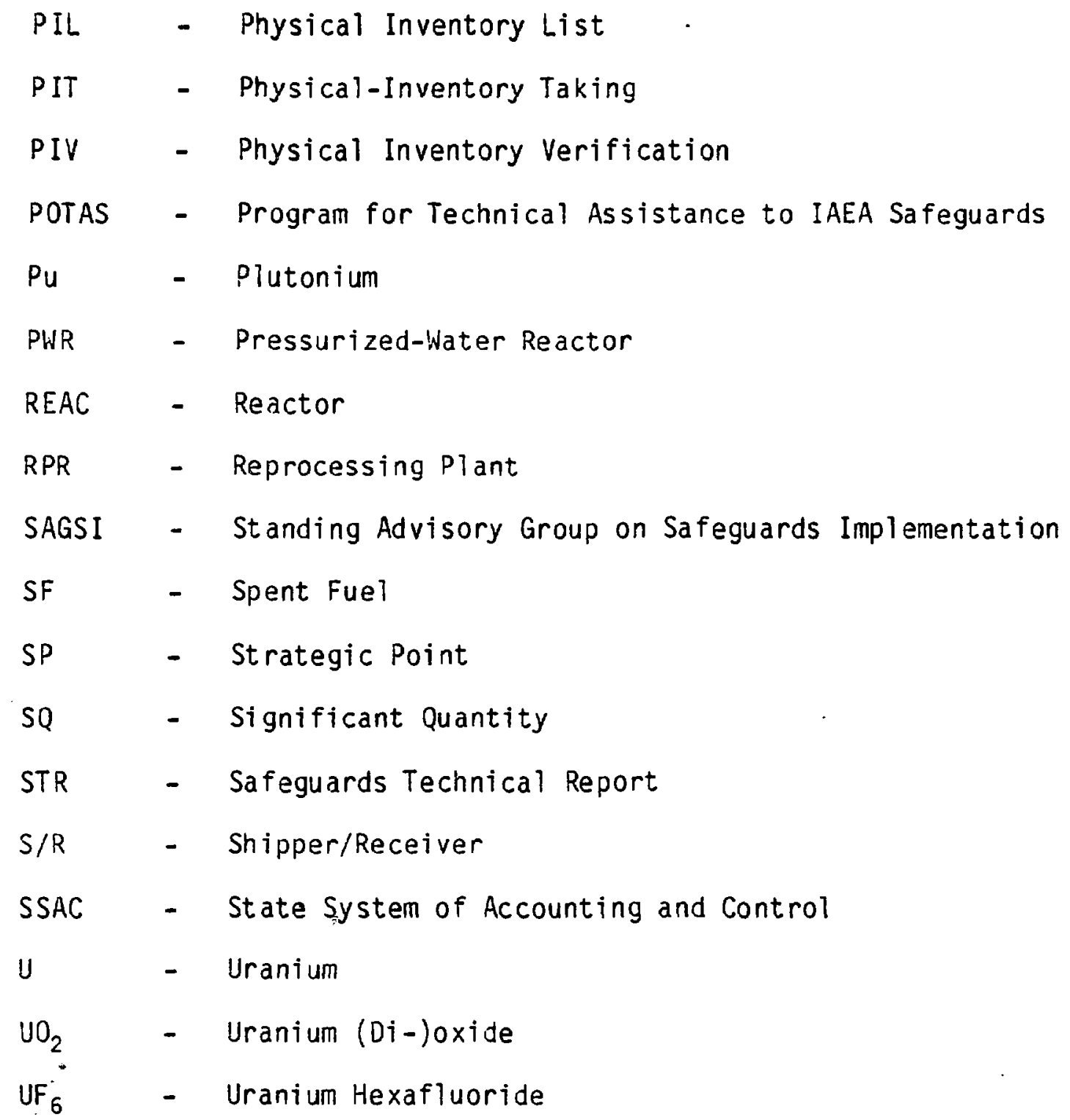


APPENDIX B: DUPLICATE SET

OF TABLES $V-1, V-2$, and $V-3$ 


\section{NOTES FOR TABLES $v-1, v-2$, and $v-3$}

Notation: $x$ represent the verification activities of the facility-oriented approach.

$Y$ represents different intensities of verification activities than $X$, but encompassing the same effort per facility.

$\Delta, \delta$ represent additional inspection activities.

$<X$ means fewer activities than $X$.

A blank box means that no activities are conducted.

\# means that activities are conducted at the number of facilities within the fuel cycle.

$<\#$ means that activities are conducted at fewer than the number of facilities within the fuel cycle.

,,+- 0 describe facility-specific changes in the number of diversion paths covered and in inspection effort with respect to the DP coverage and effort in the facility-oriented approach ("Basis").

$\mathrm{n} / \mathrm{N}$ gives the number of flow-verification inspections for a single shipment $(n)$ per facility pair (e.g., one conversion and one fabrication $p l a n t)$ and for a year's worth of shipments (N) for all such pairs in the fuel cycle. For the latter, the following assumptions apply: 12 feed and product shipments occur annually at the conversion and LEU and MOX fabrication plants; 4 each occur at the LWRs; and 24 each occur at the reprocessing plant. The nature and intensity of these verifications vary over plant types and safeguards approaches.

1 Variants I and II of the randomization-over-activities approach respectively describe the cases of reduced and equal but differently distributed overall effort with respect to the effort required by the facility-oriented approach.

2 Not recommended for future study by the Consultants (IAEA 1985).

3 For the specific change of diversion assumption discussed in section III.3.6.

4 Reactor fresh-fuel recejpts and spent-fuel inventories are verified both during PIVs and interim inventory verifications.

5 The verification of reactor fresh-fuel receipts and spent-fuel shipments in the fuel cycle with reactors only, of conversion-plant feed and of reactor spent-fuel shipments in the fuel cycles without reprocessing, and of conversion-plant feed in the closed fuel cycle could be el iminated within any approach by relying on international interdependence.

6 Includes verification during a PIV of fresh fuel going into the core, spent fuel coming out, and irradiated fuel remaining. If an annual refueling does not occur, the refueling verification is replaced by a check of the core containiment seal where applicable. 


\section{NOTES (cont'd.)}

7 Sealing only of partially filled spent-fuel casks sent from reactors.

8 Verified at all reactors once a year during the PIV.

9 Lower probability of detection than in the facility-oriented approach for each DP covered.

10 Including neutron-collar verification of fresh-fuel assemblies. This could be done at the LEU and MOX fabrication plants within the zone approach if the assemblies are then sealed. Effectiveness suggests doing the verification as late as possible before insertion into the reactor core, and zone efficiency suggests eliminating flow verifications at the fabrication plants. Of course, the collar verification could be done at the reactors within the facility approach.

11 The interim inventory period for MOX-fueled reactors is governed by the time1 iness criterion for plutonium in unirradiated MOX assemblies in the freshfuel store. This requires more frequent verifications $(\delta)$ in all approaches.

12 Inspection-effort savings from the elimination of flow verifications at facilities processing plutonium must be evaluated in light of the need to conduct interim inventory inspections to satisfy timeliness goals.

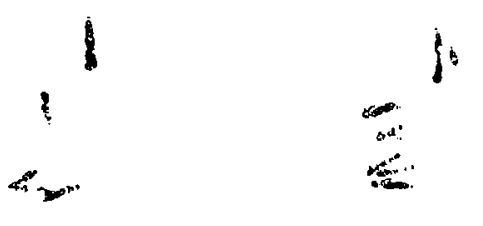


TABLE V-1. Comparison of the Approaches for a Fuel Cycle with Reactors Only

\begin{tabular}{|c|c|c|c|c|c|c|c|c|}
\hline $\begin{array}{l}\text { Information } \\
\text { Class }\end{array}$ & $\begin{array}{l}\text { Facility- } \\
\text { Or iented }\end{array}$ & $\begin{array}{l}\text { In forma- } \\
\text { tion } \\
\text { Correl a- } \\
\text { tion }\end{array}$ & Zone & $\begin{array}{l}\text { Random- } \\
\text { i zation } \\
\text { over } \\
\text { Activi- } \\
\text { ties(I) }\end{array}$ & $\begin{array}{l}\text { Randon- } \\
\text { ization } \\
\text { over } \\
\text { Activi- } \\
\text { ties(II) }\end{array}$ & $\begin{array}{l}\text { Random- } \\
\text { ization } \\
\text { over } \\
\text { Facili- } \\
\text { ties }\end{array}$ & $\begin{array}{l}\text { Goal } \\
\text { Relaxa- } \\
\text { tion } 2\end{array}$ & $\begin{array}{l}\text { As s ump- } \\
\text { tion } \\
\text { Change } 2=3\end{array}$ \\
\hline \multicolumn{9}{|l|}{ REACTORS (LEU) } \\
\hline Fresh Fuel Inventory 4,5 & $x$ & $x$ & $x$ & $<x$ & $Y$ & $<\#^{8}$ & $<x$ & $x^{8}$ \\
\hline Core Refuell ing $^{6}$ & $x$ & $x$ & $x$ & $<x$ & $Y$ & $\#$ & $<x$ & $x$ \\
\hline Spent-Fuel Inventory ${ }^{4}$ & $x$ & $x$ & $x$ & $<x$ & Y & $<\#^{8}$ & $<x$ & $x^{8}$ \\
\hline Spent-Fuel Shipnents 5,7 & $x$ & $x$ & $x$ & $<X$ & $Y$ & $<\#$ & $<x$ & \\
\hline Change in DP Coverage & Basis & 0 & 0 & $0^{9}$ & 0 & $0^{9}$ & $0^{9}$ & - \\
\hline Change in Effort & Basis & 0 & 0 & - & 0 & - & - & - \\
\hline
\end{tabular}


TABLE V-2. Comparisun of the Approaches for a tuel Cycle wilh tresil-luel facilities and Reactors

\begin{tabular}{|c|c|c|c|c|c|c|c|c|}
\hline Approach & $\begin{array}{l}\text { Facility- } \\
\text { Oriented }\end{array}$ & $\begin{array}{l}\text { Informa- } \\
\text { tion } \\
\text { Correla- } \\
\text { tion }\end{array}$ & Zone & $\begin{array}{l}\text { Randoul- } \\
\text { i zation } \\
\text { over } \\
\text { Activi- } \\
\text { ties( I) }\end{array}$ & $\left|\begin{array}{l}\text { Random- } \\
\text { ization } \\
\text { over } \\
\text { Activi- } \\
\text { ties(ii) }\end{array}\right|$ & $\begin{array}{l}\text { Randoll- } \\
\text { ization } \\
\text { over } \\
\text { Facili- } \\
\text { ties }\end{array}$ & $\begin{array}{l}\text { Goal } \\
\text { Relaxa- } \\
\text { tion? }\end{array}$ & $\begin{array}{l}\text { As s ump- } \\
\text { t ion } \\
\text { Change } 2,3\end{array}$ \\
\hline \multicolumn{9}{|l|}{ CONVERSION PLANT } \\
\hline Conversion Feed ${ }^{5}$ & $x$ & $x$ & $x$ & $<x$ & $Y$ & $x$ & $<x$ & \\
\hline Conversion Inventory & $x$ & $x$ & $x$ & $<x$ & $Y$ & $x$ & $<x$ & $x$ \\
\hline Conversion Waste & $x$ & $x$ & $x$ & $<x$ & $Y$ & $x$ & $<x$ & \\
\hline Conversion Product & $x$ & & & $<x$ & $Y$ & $x$ & $<x$ & \\
\hline Change in DP Coverage & Basis & - & - & $0^{9}$ & 0 & 0 & $0^{9}$ & - \\
\hline Change in Effort & Basis & - & - & - & 0 & 0 & - & - \\
\hline CONV-FAB Flow Verifications & $2 / 36$ & $1 / 24$ & $0 / 0$ & $2 / 36$ & $2 / 36$ & $2 /<36$ & $2 / 36$ & $0 / 0$ \\
\hline \multicolumn{9}{|l|}{ LEU FABRICATION PLANTS } \\
\hline Fabrication Feed & $x$ & $x$ & & $<x$ & Y & $<\#$ & $<x$ & \\
\hline Fabrication Inventory & $x$ & $x$ & $x$ & $<x$ & $Y$ & $\#$ & $<x$ & $x$ \\
\hline Fabrication Waste & $x$ & $x$ & $x$ & $<x$ & $Y$ & $<\#$ & $<x$ & \\
\hline Fabrication Product & $x$ & $x$ & 10 & $<x$ & $Y$ & $<\#$ & $<x$ & \\
\hline Change in DP Coverage & Basis & 0 & - & $0^{9}$ & 0 & - & $0^{9}$ & - \\
\hline Change in Effort & Basis & 0 & - & - & 0 & $0^{9}$ & - & - \\
\hline FAB-REAC Flow Verifications & $2 / 52$ & $2 / 52$ & $1 / 28$ & $2 / 52$ & $2 / 52$ & $2 /<52$ & $2 / 5 ?$ & $1 / 7$ \\
\hline
\end{tabular}


TABLE V-2 (cont'd.)

\begin{tabular}{|c|c|c|c|c|c|c|c|c|}
\hline $\begin{array}{l}\text { Information } \\
\text { Class }\end{array}$ & $\begin{array}{l}\text { Facility- } \\
\text { Oriented }\end{array}$ & $\begin{array}{l}\text { Informa- } \\
\text { tion } \\
\text { Correl a- } \\
\text { tion }\end{array}$ & Zone & $\begin{array}{l}\text { Randan- } \\
\text { ization } \\
\text { over } \\
\text { Activi- } \\
\text { ties(I) }\end{array}$ & $\left|\begin{array}{l}\text { Randon- } \\
\text { jzation } \\
\text { over } \\
\text { Activi- } \\
\text { ties(II) }\end{array}\right|$ & $\begin{array}{l}\text { Random- } \\
\text { ization } \\
\text { over } \\
\text { Facili- } \\
\text { ties }\end{array}$ & $\begin{array}{l}\text { Goal } \\
\text { Relaxa- } \\
\text { tion }{ }^{2}\end{array}$ & $\begin{array}{l}\text { As sump- } \\
\text { t ion } \\
\text { Change }^{2,3}\end{array}$ \\
\hline \multicolumn{9}{|l|}{ REACTORS (LEU) } \\
\hline Fresh Fuel Inventory ${ }^{4}$ & $x$ & $x$ & $x+\Delta^{10}$ & $<x$ & Y & $\angle \#^{\theta}$ & $<x$ & $x^{8}$ \\
\hline Core Refuell ing ${ }^{6}$ & $x$ & $x$ & $x$ & $<x$ & $Y$ & $\#$ & $<x$ & $x$ \\
\hline Spent-Fuel Inventory 4 & $x$ & $x$ & $x$ & $<x$ & $Y$ & $<^{8}$ & $<x$ & $x^{2}$ \\
\hline Spent-Fuel Shipments ${ }^{5,7}$ & $x$ & $x$ & $x$ & $<x$ & Y & $<\#$ & $<x$ & \\
\hline Change in DP Coverage & Basis & 0 & + & $0^{9}$ & 0 & $0^{9}$ & $0^{9}$ & - \\
\hline Change in Effort & Basis & 0 & + & - & 0 & - & - & - \\
\hline
\end{tabular}


TABLE V-3. Comparison of the Mproaches for a Closed Fuel Cycle

\begin{tabular}{|c|c|c|c|c|c|c|c|c|}
\hline Approach & $\begin{array}{l}\text { Facility- } \\
\text { Or iented }\end{array}$ & $\begin{array}{l}\text { In forma- } \\
\text { tion } \\
\text { Correla- } \\
\text { tion }\end{array}$ & Zone & $\begin{array}{l}\text { Randoin- } \\
\text { ization } \\
\text { over } \\
\text { Activi- } \\
\text { ties(I) }\end{array}$ & $\mid \begin{array}{l}\text { Randonl- } \\
\text { i zation } \\
\text { over } \\
\text { Activi- } \\
\text { ties(II) }\end{array}$ & $\begin{array}{l}\text { Randon- } \\
\text { ization } \\
\text { over } \\
\text { Facili- } \\
\text { ties }\end{array}$ & $\begin{array}{l}\text { Goal } \\
\text { Relaxa- } \\
\text { tion }{ }^{2}\end{array}$ & $\begin{array}{l}\text { As s ump- } \\
\text { tion } \\
\text { Change } 2,3\end{array}$ \\
\hline \multicolumn{9}{|l|}{ CONVERSION PLANT } \\
\hline Conversion Feed ${ }^{5}$ & $x$ & $x$ & $x$ & $<x$ & $Y$ & $x$ & $<x$ & \\
\hline Conversion Inventory & $x$ & $x$ & $x$ & $<x$ & $Y$ & $x$ & $<x$ & \\
\hline Conversion Waste & $x$ & $x$ & $x$ & $<x$ & $Y$ & $x$ & $<x$ & \\
\hline Conversion Product & $x$ & & & $<x$ & $Y$ & $x$ & $<x$ & \\
\hline Change in DP Coverage & Basis & - & - & $0^{9}$ & 0 & 0 & $0^{9}$ & Same \\
\hline Change in Effort & Basis & - & - & - & 0 & 0 & - & \\
\hline CONV-FAB Flow Verifications & $2 / 48$ & $1 / 36$ & $0 / 0$ & $2 / 48$ & $2 / 48$ & $2 /<48$ & $2 / 48$ & as \\
\hline \multicolumn{9}{|l|}{ LEU FABRICATION PLANTS } \\
\hline Fabrication Feed & $x$ & $x$ & & $<x$ & $Y$ & $<\#$ & $<x$ & Facility- \\
\hline Fabrication Inventory & $x$ & $x$ & $x$ & $<x$ & $Y$ & $\#$ & $<x$ & \\
\hline Fabrication Waste & $x$ & $x$ & $x$ & $<x$ & $\gamma$ & $<\#$ & $<x$ & oriented \\
\hline Fabrication Product & $x$ & $x$ & 10 & $<x$ & $\gamma$ & $<\#$ & $<x$ & \\
\hline Change in $\mathrm{CP}$ Coverage & Basis & 0 & - & $0^{9}$ & 0 & $0^{9}$ & $0^{9}$ & \\
\hline Change in Effort & Basis & 0 & - & - & 0 & - & - & \\
\hline FAB-REAC Flow Verifications & $2 / 120$ & $2 / 120$ & $1 / 84$ & $2 / 120$ & $2 / 120$ & $2 /<120$ & $2 / 120$ & \\
\hline
\end{tabular}


TABLE V-3 (cont'd.)

\begin{tabular}{|c|c|c|c|c|c|c|c|c|}
\hline Approach & $\mid \begin{array}{l}\text { Facility- } \\
\text { Oriented }\end{array}$ & $\begin{array}{l}\text { In forma- } \\
\text { tion } \\
\text { Correl a- } \\
\text { tion }\end{array}$ & Zone & $\begin{array}{l}\text { Random- } \\
\text { ization } \\
\text { over } \\
\text { Activi- } \\
\text { ties( } 1)^{2}\end{array}$ & $\begin{array}{l}\text { Random- } \\
\text { ization } \\
\text { over } \\
\text { Activi- } \\
\text { ties(II) }\end{array}$ & $\begin{array}{l}\text { Randon- } \\
\text { ization } \\
\text { over } \\
\text { Facili- } \\
\text { ties }\end{array}$ & $\begin{array}{l}\text { Goal } \\
\text { Relaxa- } \\
\text { tion }\end{array}$ & $\begin{array}{l}\text { As sump- } \\
\text { t i on } \\
\text { Change } 2,3\end{array}$ \\
\hline \multicolumn{9}{|l|}{ REACTORS (LEIJ and MOX) } \\
\hline Fresh-Fuel Inventory 4,11 & $x+\delta$ & $x+\delta$ & $x+\delta+\Delta^{10}$ & $<x+\delta$ & $\gamma+\delta$ & $<\#^{8}$ & $<x+\delta$ & Same \\
\hline Core Refueling ${ }^{6}$ & $x$ & $x$ & $x$ & $<x$ & $\gamma$ & $\#$ & $<x$ & \\
\hline Spent-Fuel Inventory ${ }^{4}$ & $x$ & $x$ & $x$ & $<x$ & $\gamma$ & $\left\langle \#^{8}\right.$ & $<x$ & as \\
\hline Spent-Fuel Shipments ${ }^{7}$ & $x$ & & & $<x$ & Y & $<\#$ & $<x$ & \\
\hline Change in DP Coverage & Basis & $\mathbf{0}$ & - & $0^{9}$ & 0 & $0^{9}$ & $0^{9}$ & Facility \\
\hline Change in Ef fort & Basis & 0 & + & - & 0 & - & - & \\
\hline REAC-RPR Fl ow Verifications & $2 / 108$ & $1 / 84$ & $0 / 0$ & $2 / 108$ & $2 / 108$ & $2 /<108$ & $2 / 108$ & Oriented \\
\hline
\end{tabular}


TABLE V-3 (cont'd.)

\begin{tabular}{|c|c|c|c|c|c|c|c|c|}
\hline Approach & $\begin{array}{l}\text { Facility- } \\
\text { Or iented }\end{array}$ & $\begin{array}{l}\text { In forma- } \\
\text { tion } \\
\text { Correla- } \\
\text { tion }\end{array}$ & Zone & $\begin{array}{l}\text { Randon- } \\
\text { jzation } \\
\text { over } \\
\text { Activi- } \\
\text { ties(I) I }\end{array}$ & \begin{tabular}{|} 
Random- \\
ization \\
over \\
Activi- \\
ties(II)
\end{tabular} & $\begin{array}{l}\text { Rand on- } \\
\text { jzation } \\
\text { over } \\
\text { Facili- } \\
\text { ties }\end{array}$ & $\begin{array}{l}\text { Goal } \\
\text { Rel axa- } \\
\text { tion }{ }^{2}\end{array}$ & $\begin{array}{l}\text { As sump- } \\
\text { t ion } \\
\text { Change }{ }^{2,3}\end{array}$ \\
\hline \multicolumn{9}{|l|}{ REPROCESS ING PLANT } \\
\hline Spent-Fuel Receipts & $x$ & $x$ & 12 & $<x$ & Y & $x$ & $<x$ & Same \\
\hline Spent-Fuel Inventory & $x$ & $x$ & $x$ & $<x$ & Y & $x$ & $<x$ & \\
\hline Spent-Fuel Dissolution & $x$ & $x$ & $x$ & $<x$ & Y & $x$ & $<x$ & \\
\hline Product, Process Inventory & $x$ & $x$ & $x$ & $<x$ & Y & $x$ & $<x$ & as \\
\hline Waste & $x$ & $x$ & $x$ & $<x$ & Y & $x$ & $<x$ & \\
\hline Product (Pu \& U) Shipnents & $x$ & $x$ & 12 & $<x$ & $Y$ & $x$ & $<x$ & Facility \\
\hline Change in DP Coverage & Basis & $\mathbf{0}$ & - & $0^{9}$ & 0 & 0 & $0^{9}$ & \\
\hline Change in Effort & Basis & $\mathbf{0}$ & - & - & $\mathbf{0}$ & 0 & - & Oriented \\
\hline RPR-MFAB Flow Verifications & $2 / 60$ & $1 / 24$ & $0 / 0$ & $2 / 60$ & $2 / 60$ & $2 /<60$ & $2 / 60$ & \\
\hline
\end{tabular}


TABLE V-3 (cont'd.)

\begin{tabular}{|c|c|c|c|c|c|c|c|c|}
\hline Approach & $\begin{array}{l}\text { Facility- } \\
\text { Oriented }\end{array}$ & $\begin{array}{l}\text { In forma- } \\
\text { t ion } \\
\text { Correla- } \\
\text { tion }\end{array}$ & Zone & $\begin{array}{l}\text { Randont- } \\
\text { i zation } \\
\text { over } \\
\text { Activi- } \\
\text { ties(I)l }\end{array}$ & \begin{tabular}{|l} 
Random- \\
ization \\
over \\
Activi- \\
ties( II)
\end{tabular} & $\begin{array}{l}\text { Random- } \\
\text { ization } \\
\text { over } \\
\text { Facili- } \\
\text { ties }\end{array}$ & $\begin{array}{l}\text { Goal } \\
\text { Relaxa- } \\
\text { tion }{ }^{2}\end{array}$ & $\begin{array}{l}\text { As sump- } \\
\text { tion } \\
\text { Change } 2.3\end{array}$ \\
\hline \multicolumn{9}{|l|}{ MOX FABR ICATION PLANTS } \\
\hline MOX Feed & $x$ & 12 & 12 & $<x$ & Y & $<\#$ & $<x$ & \\
\hline MOX Inventory (PIV) & $x$ & $x$ & $x$ & $<x$ & $Y$ & $\#$ & $<x$ & Same \\
\hline MOX Inventory (Interim) & $x$ & $x$ & $x$ & $<x$ & Y & $<\#$ & $<x$ & \\
\hline MOX Waste & $x$ & $x$ & $x$ & $<x$ & Y & $<\#$ & $<x$ & as \\
\hline MOX Product & $x$ & $x$ & 10,12 & $<x$ & Y & $<\#$ & $<x$ & \\
\hline Change in DP Coverage & Basis & - & - & $0^{9}$ & 0 & $0^{9}$ & $0^{9}$ & Facility \\
\hline Change in Effort & Basis & - & - & - & 0 & - & - & \\
\hline MOX-REAC Fl ow Verifications & $2 / 120$ & $2 / 120$ & $1 / 84$ & $2 / 120$ & $2 / 120$ & $2 /<120$ & $2 / 120$ & Oriented \\
\hline
\end{tabular}

